\title{
NBSIR 74.473
}

\section{Natural Disasters: Some Empirical and Economic Considerations}

G. Thomas Sav

Building Economies Section

Center for Building Technology

Institute for Applied Technology

National Bureau of Standards

Washington, D. C. 20234

February, 1974

Final Report

Prepared for

Office of Federal Building Technology

Center for Building Technology Institute for Applied Technology

National Bureau of Standards 

NBSIR $74-473$

\section{NATURAL DISASTERS: SOME EMPIRICAL}

\section{AND ECONOMIC CONSIDERATIONS}

G. Thomas Sav

Building Economics Section

Center for Building Technology

Institute for Applied Technology

National Bureau of Standards

Washington, D. C. 20234

February, 1974

Final Report

Prepared for

Office of Federal Building Technology

Center for Building Technology

Institute for Applied Technology

National Bureau of Standards

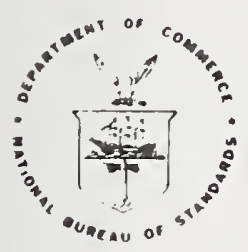

U. S. DEPARTMENT OF COMMERCE, Frederick B. Dent, Secretary

NATIONAL BUREAU OF STANDARDS, Richard W. Roberts, Director 

This study was conducted for the Office of Federal Building Technology in the Center for Building Technology, Institute for Applied Technology, National Bureau of Standards. $\mathrm{Dr}$. Charles Culver and Mr. Samuel Kramer, both of that Office, provided initial direction for the study. Dr. Harold E. Marshall, Building Economics Section, contributed valuable economic skills and editorial comments throughout the study. Dr. Peter F。Colwell, also of the Building Economics Section, was extremely helpful in his review. of the paper.

Appreciation is extended for providing significant data for this study to the American Red Cross, Washington, D.C.; the Federal Disaster Assistance Administration, Washington, D.C.; and the National Climatic Center, Asheville, N.C. 


\section{ABSTRACT}

This study examines the extent of some of the losses resulting from natural disasters. An estimate of these losses is necessary in order to determine the potential benefits that might be realized from mitigating the negative economic impacts from natural disasters. Absolute and relative losses resulting from hurricanes, floods, earthquakes and tornadoes are examined. These data will help individuals, communities, and the Federal government make better decisions as to how and to what extent protection against disasters should be provided. The application of benefit-cost analysis for choosing the optimal level of protection against disasters is also discussed. Recommendations are made for further research in determining the economic feasibility of various techniques designed to mitigate the losses from disasters. 
PREFACE. . . . . . . . . . . . . . . . . . . 1 ABSTRACT ................................

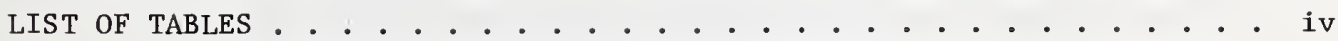
LIST OF FIGURES. . . . . . . . . . . . . . . . . . . vi

1. INTRODUCTION ............................... 1

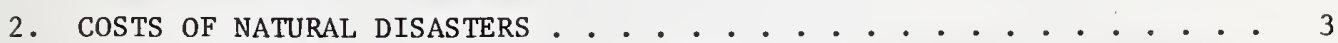

2.1 HURRICANES. . . . . . . . . . . . . . . 3

2.2 FLOODS. . . . . . . . . . . . . . . . 12

2.3 EARTHQUAKES .................... 21

2.4 TORNADOES . . . . . . . . . . . . . . . . 30

3. BENEFIT-COST ANALYSIS. . . . . . . . . . . . . 42

3.1 BENEFIT-COST MODELS FOR DISASTER MITIGATION . . . . . . . 42

3.2 APPLICATION OF BENEFIT-COST ANALYSIS TO DISASTER MITIGATION • . 46

4. SUMMARY AND RECOMMENDATIONS. . . . . . . . . . . . . 53

4.1 SUMMARY . . . . . . . . . . . . . . . . 53

4.2 RECOMMENDATIONS FOR FURTHER RESEARCH. . . . . . . . . . 58

APPENDIX: ECONOMIC BFFICIENCY: MAXIMIZING NET BENEFITS OR MINIMIZING TOTAL COSTS (COSTS PLUS LOSSES) ?............... . . 60 SELECTED BIBLIOGRAPHY. . . . . . . . . . . . . . . 62 


\section{LIST OF TABLES}

Table

Page

2.1 Loss of Life and Property Damage in the United States Due to Hurricanes, By Five-Year Periods, 1925-1969, and 1970. . . . . 4

2.2 Estimated Lives Lost and Damages in the United States Due to North Atlantic Tropical Cyclones, By Year, 1915-1970 . . . . 6

2.3 Lives Lost and Damages Due to Hurricane Wind and Storm Surge Hazards Along the Gulf and South Atlantic Coastlines, 1900-1970。 - 8

2.4 Data on Hurricanes Involving More than Five Families . . . . . . 11

2.5 Selected Data from Hurricane Agnes ............. 13

2.6 Most Destructive Hurricanes in the United States, 1930-1972. • . 14

2.7 Dollar Losses Resulting from Floods, By State and Year, 1955-1971. 17

2.8 Number of Lives Lost and Amount of Property Damages in the United States Due to Floods for Five-Year Periods, 1925-1969 • 。 19

2.9 Average Number of Lives Lost and Amount of Property Damages in the United States Due to Floods, By Month for the Period 1925-1971. . . . . . . . . . . . . 20

2.10 Severe River Flood Disasters in the United States, 1935-1969 . . 22

2.11 Casualities, Physical Damage, and Estimated Pecuniary Losses Due to Agnes Floods. ................. 23

2.12 Selected Data for Floods and Flash Floods. . . . . . . . 24

2.13 Property Damages Resulting from Major U.S. Earthquakes,

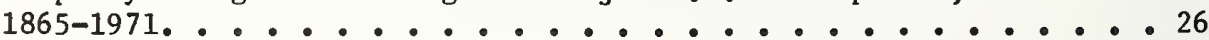

2.14 Lives Lost and Value of Property Damages in the United States Due to Earthquakes from 1925-1964 by Five-Year Periods, and for 1965 . . . . . . . . . . . . 29

2.15 Data for Five Severe Earthquakes in the United States. . . . . 31

2.16 Estimated Damages to Federal Facilities in Alaska Resulting from the 1964 Earthquake . . . . . . . . . . . 32

2.17 Losses Due to the San Fernando Earthquake by Private and

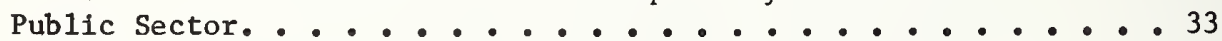

2.18 Frequency of Tornadoes, Resulting Casualties, and Property Losses, 1916-1972. . . . . . . . . . . . 34 


\section{LIST OF TABLES--continued}

$\underline{\text { Table }}$

2.19. Selected Data on the Impact of Tornadoes that Affect More Than Five Families .............. . . 39

2.20 Casualties and Losses from Severe Tornadoes, 1955-1971 . . . . 40

2.21 Property Damages Resulting from Individual Tornadoes . . . . . 41

3.1 Damage Reduction Due to Increasing Percent of Population

Protecting Against Hurricanes. . . . . . . . . 49

3.2 Damage Reduction with Population Growth and Increased

Protection by Population ............ 50 


\section{LIST OF FIGURES}

Figure

Page

1.1 Annual Number of Disasters Causing Losses on Insured Property

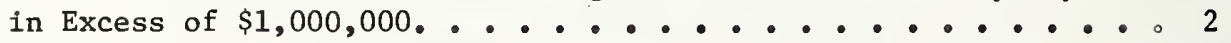

2.1 Trends of Damages and Deaths Due to Hurricanes in the

United States.................... 5

2.2 Selected Hurricane Paths, Deaths, and Damages in the United States, 1964-1970 ................ 7

2.3 Flood Losses in the United States by Major River Systems,

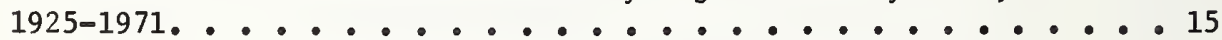

2.4 Number of Floods Resulting in Assistance from the American

Red Cross, 1955-1971 ................ 18

2.5 Seismic Risk Map of the United States. . . . . . . . . 27

2.6 Destructive Earthquakes in the United States through 1966. . . 28

2.7 Tornado Incidence by State, 1953-1970........... 35

2.8 Distribution of Tornado Incidence and Resulting Deaths by

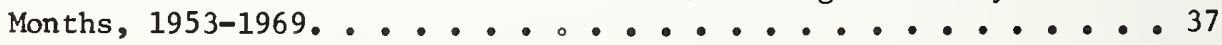

2.9 Deaths Due to Tornadoes, by State, 1953-1969 ....... 38

3.1 Dollar Value of Total Benefits and Total Costs Versus Level of

Protection Against Natural Disasters . . . . . . . . 43

3.2 Dollar Value of Marginal Benefits and Marginal Costs Versus

Level of Protection Against Natural Disasters. . . . . . . 43

3.3 Dollar Value of Total Losses, Costs of Protection, and Total

costs versus Level of Protection Against Natural Disasters . . . 45

3.4 Earthquake Damage--California Schools. . . . . . . . 47

3.5 Earthquake Damage--California Schools, Puget Sound (King County)

Schools, and Anchorage Schools .............. 47

3.6 Hurricane Decision Matrix。.............. 51

4.1 Property Damages Resulting from Hurricanes, Floods, Tornadoes, and Earthquakes. . . . . . . . . . . . . 54 
4.2 Number of Lives Lost Due to Hurricanes, Floods, Tornadoes, and Earthquakes. . . . . . . . . . . . . . . 55

4.3 Comparisons of Property Damages and Number of Lives Lost for Individua1 Diasters, 1970-1972 . . . . . . . . . . . . 56

4.4 Comparisons of Number of Dwellings Destroyed and Damaged for Individual Disasters, 1970-1972. . . . . . . . . . . . 57 



\section{INTRODUCTION}

Natural disasters cost the United States about a billion dollars each year. More recently, these costs have exceeded the billion dollar level. In 1973 more than $\$ 1.2$ billion worth of property was damaged as a result of natural disasters. ${ }^{1}$ During 1972 estimated property damages amounted to $\$ 3.5$ billion. Such losses tend to represent the cost of restoring physical structures to their pre-disaster condition. However, they do not measure the full economic impact of natural disasters. Dollar losses usually fail to include the losses in human lives, losses due to human suffering, losses in productivity, losses in the tax base and tax revenues, and social disruptions resulting from disasters.

The real property losses due to natural disasters show an increasing trend over time. ${ }^{3}$ Figure 1.1 shows the annual number of disasters which caused losses (on insured property) in excess of $\$ 1,000,000$. An upward trend in the number of occurrences causing such losses is also indicated by Figure 1.1. Several factors may be responsible for this trend. First a demographic shift to disaster prone areas increases potential losses. Second, changing property values are reflected in any time series comparison of nominal dollar property losses. Another factor that might be responsible for increasing losses would be an increase in the frequency and severity of natural phenomena; e.g., hurricanes, floods, earthquakes, and tornadoes. A fourth possibilizy is a reduction in society's level of disaster preparedness relative to its increasing need for disaster protection.

Chapter 2 catalogues past losses from natural disasters. Four major types of natural phenomena are examined: hurricanes, floods, earthquakes, and tornadoes. Because existing sources have not been consistent in reporting past losses for a particular type of disaster or among different types of disasters, this study is a selective survey of losses rather than an extensive analysis of the economic impacts resulting from natural disasters.

A uniform approach is taken to describe the losses produced by each of the four natural phenomena. First, the distribution of dollar losses with respect to time is discussed. Next, an effort is made to extract a trend from the annual dollar losses and physical losses (e.g., lives lost, families suffering loss, and buildings destroyed). Thirdly, comparison is made of the losses incurred during several severe disasters in the United States. Finally, there is a discussion of the impact that a single natural disaster generates. Examples are provided for hurricanes, floods, and earthquakes.

In Chapter 3, benefit-cost analysis is discussed as a method of determining the most efficient level of disaster protection; i.e., the level of protection that maximizes society's net benefits.

The final chapter compares the relative losses of different types of disasters and discusses possible techniques for mitigating losses due to natural disasters. Recommendations for further research are made on the basis of the conclusions drawn from this paper.

\footnotetext{
${ }^{1}$ Federal Disaster Assistance Administration, News Release HUD No. 74-DA-1, January 4, 1974.

2 Ibid.

3 Douglas C. Dacy and Howard Kunreuther, The Economics of Natural Disasters (New York: The Free Press, 1969), p. 12.
} 
的

Figure 1.1 Annual number of disasters causing losses on insured property in excess of $\$ 1,000,000$.

Source: Don G. Friedman, "Prospective View of Natural Disasters in the United States," a paper presented at The System Safety Society Symposium, July 18, 1973. 


\section{COSTS OF NATURAL DISASTERS}

\subsection{Hurricanes}

The destruction caused by hurricanes is the result of high winds, of storm surges which are themselves produced by high winds, and of flooding produced by heavy rainfall. For days after a hurricane has passed, its flood producing rains may continue to take lives and destroy property. The destruction resulting from these floods may be proportionately greater than that due to the winds produced during the hurricane. For example, Hurricane Agnes produced devastating floods while its winds were relatively less damaging.

The real property losses resulting from hurricanes have been increasing through time. For the period 1934-1964 Dacy and Kunreuther have estimated that hurricane damages have increased annually at a rate of $4.5 \%$; they also report that the annual rate of increase since 1950 has been $10.5 \%$ Table 2.1 shows that the property losses for the 1965-1969 period ( $\$ 3,091$ million) increased by more than $96 \%$ ( $\$ 1,515$ million) over the previous five year period losses $(\$ 1,576$ million). Figure 2.1 depicts this trend by five-year intervals for the period 1915-1969 (Table 2.2 shows a year by year account of these losses and the number of lives 1ost, 1915-1970). Dollar damages are measured in constant 1957-1959 dollars. One cause of the upward trend is probably the rapid economic development of the areas subject to hurricane damige.

In addition to increasing property damages there may be an increasing potential for the loss of lives as the population density in hurricane prone areas increases (Figure 2.2 gives an indication of hurricane prone areas by showing the paths of six severe hurricanes, 1964-1970). However, Figure 2.1 indicates deaths due to hurricanes have exhibited a decreasing trend over the years 1900-1969. This could be attributed to advancements in hurricane watch and warning systems and their advancements in the dissemination of information.

The numbers of lives lost and the damages resulting from individual hurricanes have been anything but stable. Fluctuations in the magnitudes of impact from specific hurricanes is evidenced in Table 2.3. Damages range from $\$ 170,000$ and no lives reported loşt (September $21-29,1917$ ) to $\$ 1,420,700$ in damages and 256 lives lost (August 5-22, 1969).

Table 2.4 shows numbers of deaths, numbers of people injured, numbers of people given emergency care, and numbers of people suffering losses as a result of hurricanes. These losses have not been monetized. However, one could attempt to estimate the implicit monetary value due, for example, to losses of human lives. One interpretation of the social cost of a human life (human capital) is the net loss in the productive value which that individual would provide to society over his expected remaining life span. However, this cost does not reflect the pain and suffering or psychological impact which premature deaths have on relatives and friends. Nor does it show, for example, the loss in a community's tax base due to deaths, injuries, or illnesses.

${ }^{1}$ Douglas C. Dacy and Howard Kunreuther, The Economics of Natural Disasters (New York: The Free Press, 1969), p. 17.

2 To determine the real value of dollar losses over time, a price index based on the real purchasing power of a dollar in a given year should be used to inflate (or deflate) nominal dollar values for other years. 
TABLE 2.1

LOSS OF LIFE AND PROPERTY DAMAGE IN THE UNITED STATES DUE TO HURRICANES, BY FIVE-YEAR PERIODS, 1925-1969, AND 1970

\begin{tabular}{ccc} 
Years & $\begin{array}{c}\text { Property Loss } \\
(\$ 1,000,000)\end{array}$ & $\begin{array}{c}\text { Number of Lives } \\
\text { Lost }\end{array}$ \\
\hline $1925-1929$ & 133 & 2114 \\
$1930-1934$ & 51 & 80 \\
$1935-1939$ & 314 & 1026 \\
$1940-1944$ & 222 & 149 \\
$1945-1949$ & 298 & 67 \\
$1950-1954$ & 802 & 217 \\
$1955-1959$ & 539 & 660 \\
$1960-1964$ & 1576 & 175 \\
$1965-1969$ & 3091 & 412 \\
1970 & 454 & \\
\hline
\end{tabular}

Source: Douglas C. Dacy and Howard Kunreuther, The Economics of Natural Disasters (New York: The Free Press, 1969), p. 6, data for 1925-1964; and Executive Office of the President, Office of Emergency Preparedness, Disaster Preparedness, Vo1. 3 (Washington, D. C.: Government Printing Office, January 1972), p. 46, data for 1965-1969, and 1970 . 


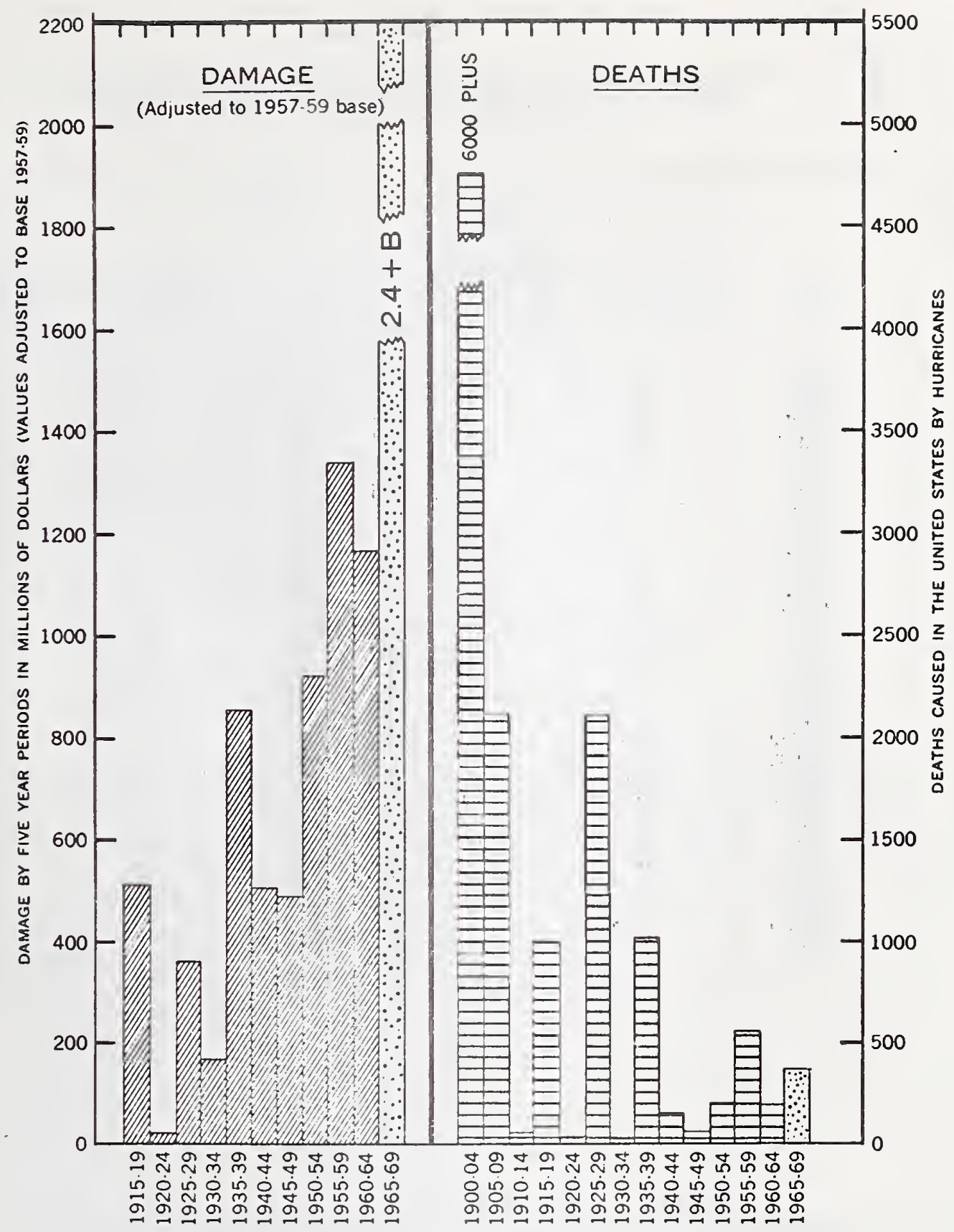

Figure 2.1 Trends of damages and deaths due to hurricanes in the United States

Source: Executive Office of the President, Office of Emergency Preparedness, Disaster Preparedness, Vol. 3 (Washington, D.C.: Government Printing Office; January 1972), p. 42. 
ESTIMATED LIVES LOST AND DAMAGES IN THE UNITED STATES DUE TO

NORTH ATLANTIC TROPICAL CYCLONES, BY YEAR, 1915-1970.

\begin{tabular}{|c|c|c|c|c|c|}
\hline Year & $\begin{array}{l}\text { Number of } \\
\text { Lives Lost }\end{array}$ & $\begin{array}{l}\text { Damages } \\
(\$ 1,000,000)\end{array}$ & Year & $\begin{array}{l}\text { Number of } \\
\text { Lives Lost }\end{array}$ & $\begin{array}{l}\text { Damages } \\
(\$ 1,000,000)\end{array}$ \\
\hline $\begin{array}{l}1915 \\
1916 \\
1917 \\
1918 \\
1919 \\
1920 \\
1921 \\
1922 \\
1923 \\
1924 \\
1925 \\
1926 \\
1927 \\
1928 \\
1929 \\
1930 \\
1931 \\
1932 \\
1933 \\
1934 \\
1935 \\
1936 \\
1937 \\
1938 \\
1939 \\
1940 \\
1941 \\
1942\end{array}$ & $\begin{array}{r}600 \\
107 \\
5 \\
34 \\
287 \\
2 \\
5 \\
0 \\
0 \\
2 \\
6 \\
269 \\
0 \\
1,836 \\
3 \\
0 \\
0 \\
0 \\
63 \\
17 \\
414 \\
9 \\
0 \\
600 \\
3 \\
51 \\
10 \\
8\end{array}$ & $\begin{array}{r}63.0 \\
33.3 \\
0.2 \\
5.0 \\
22.0 \\
3.0 \\
3.0 \\
0 \\
\text { Minor } \\
\text { Minor } \\
\text { Minor } \\
106.5 \\
0 \\
25.0 \\
0.7 \\
\text { Minor } \\
0 \\
0 \\
46.7 \\
4.8 \\
11.5 \\
2.3 \\
\text { Minor } \\
300.2 \\
\text { Minor } \\
4.7 \\
7.7 \\
27.1\end{array}$ & $\begin{array}{l}1943 \\
1944 \\
1945 \\
1946 \\
1947 \\
1948 \\
1949 \\
1950 \\
1951 \\
1952 \\
1953 \\
1954 \\
1955 \\
1956 \\
1957 \\
1958 \\
1959 \\
1960 \\
1961 \\
1962 \\
1963 \\
1964 \\
1965 \\
1966 \\
1967 \\
1968 \\
1969 \\
1970 \\
\text { Total }\end{array}$ & $\begin{array}{r}16 \\
64 \\
7 \\
0 \\
53 \\
3 \\
4 \\
4 \\
19 \\
0 \\
3 \\
2 \\
193 \\
218 \\
21 \\
395 \\
2 \\
24 \\
65 \\
46 \\
4 \\
10 \\
49 \\
75 \\
54 \\
18 \\
9 \\
256 \\
11 \\
5.953\end{array}$ & $\begin{array}{r}16.8 \\
165.0 \\
80.1 \\
5.2 \\
135.8 \\
18.4 \\
58.8 \\
35.9 \\
2.0 \\
2.8 \\
6.2 \\
755.5 \\
984.5 \\
26.5 \\
152.1 \\
11.2 \\
23.1 \\
370.4 \\
331.0 \\
1.1 \\
13.0 \\
515.2 \\
1.446 .0 \\
15.0 \\
200.0 \\
10.0 \\
1,420.0 \\
454.0 \\
7.922 .3\end{array}$ \\
\hline
\end{tabular}

Source: Executive Office of the President, Office of Emergency Preparedness, Disaster Preparedness, Vol. 3 (Washington, D. C.: Government Printing Office, January 1972), p. 46. 


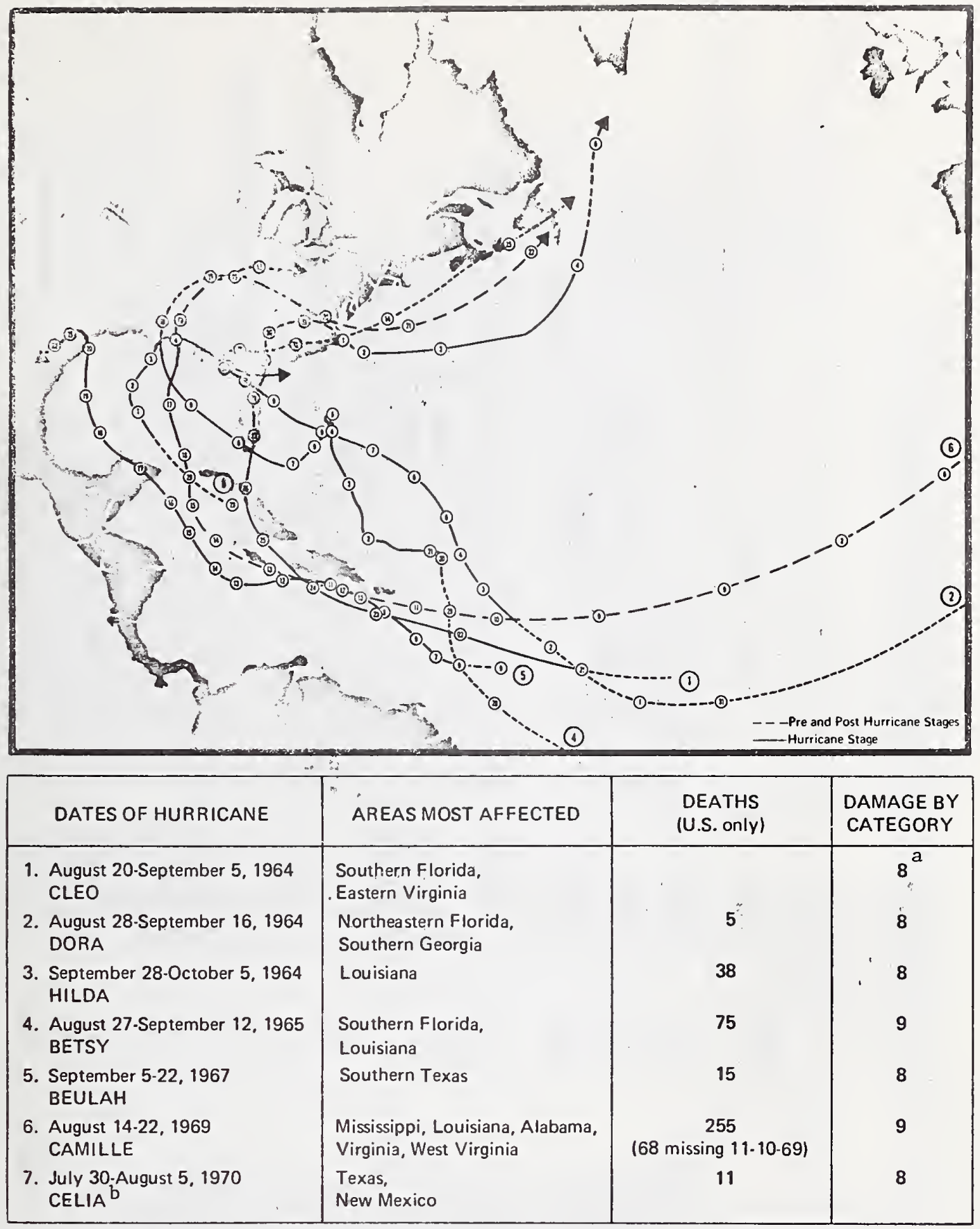

Figure 2.2 Selected hurricane paths, deaths, and damages in the United States, 1964-1970

$\begin{aligned} \text { a Damage Categories: } & \begin{array}{l}\text { Category } 8-- \\ \text { Category } 90--\$ 500 \text { million to } \$ 500 \text { million. }\end{array} \\ & \text { Cato } \$ 5 \text { billion. }\end{aligned}$

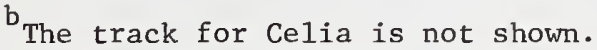

Source: Executive Office of the President, Office of Emergency Preparedness, Disaster Preparedness, Vol. 3 (Washington, D.C.: Government Printing Office, January 1972), p. 47. 


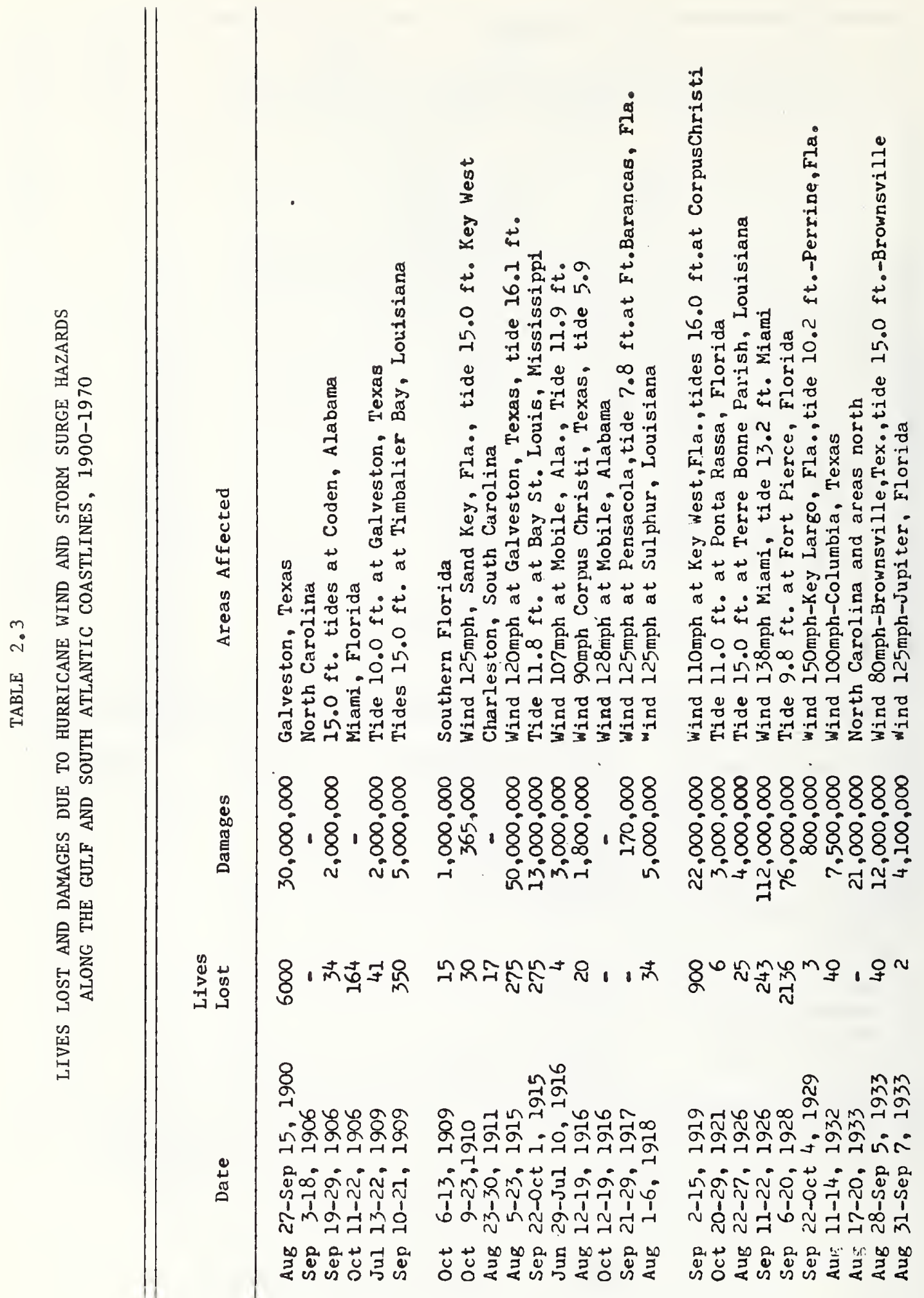




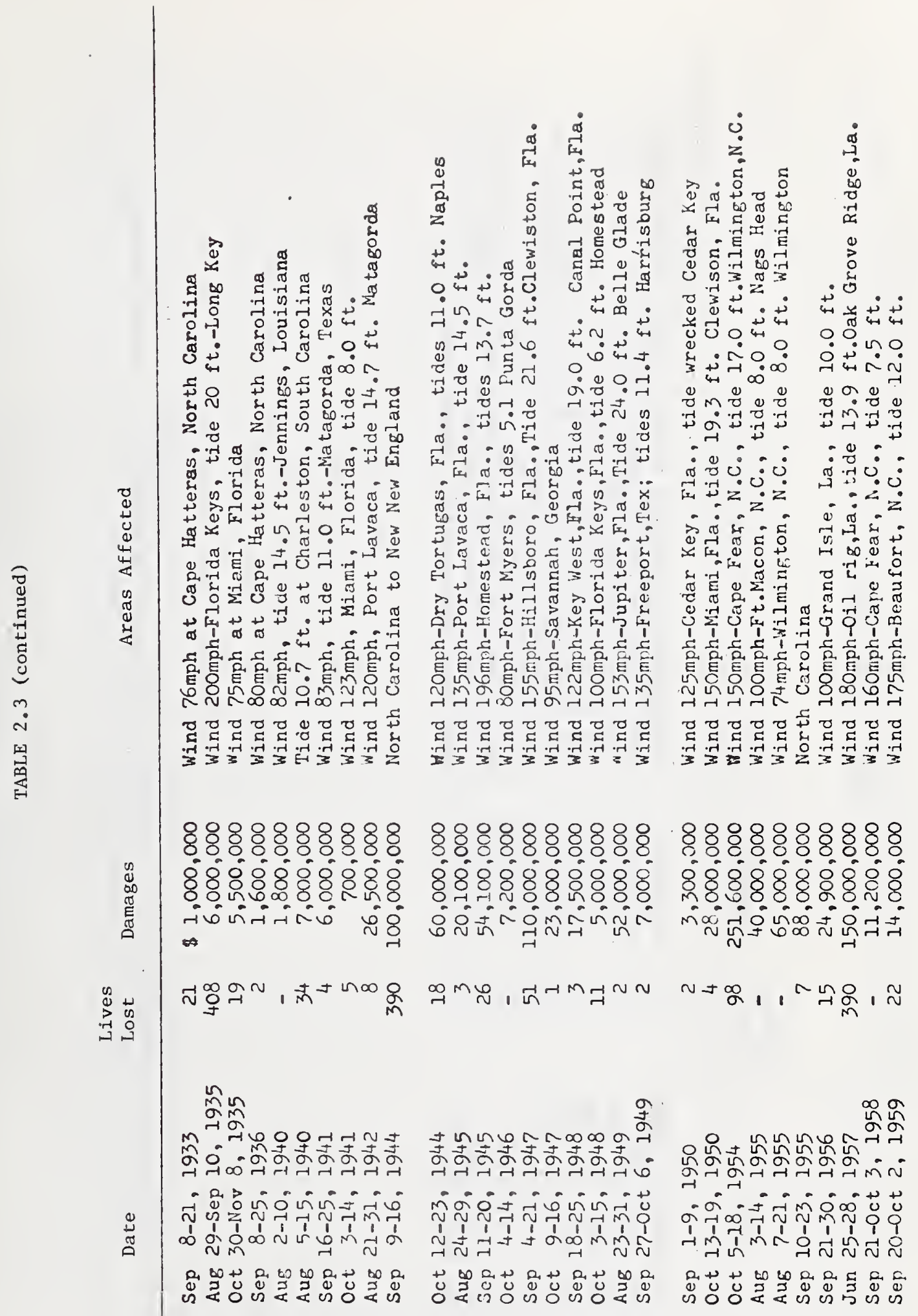




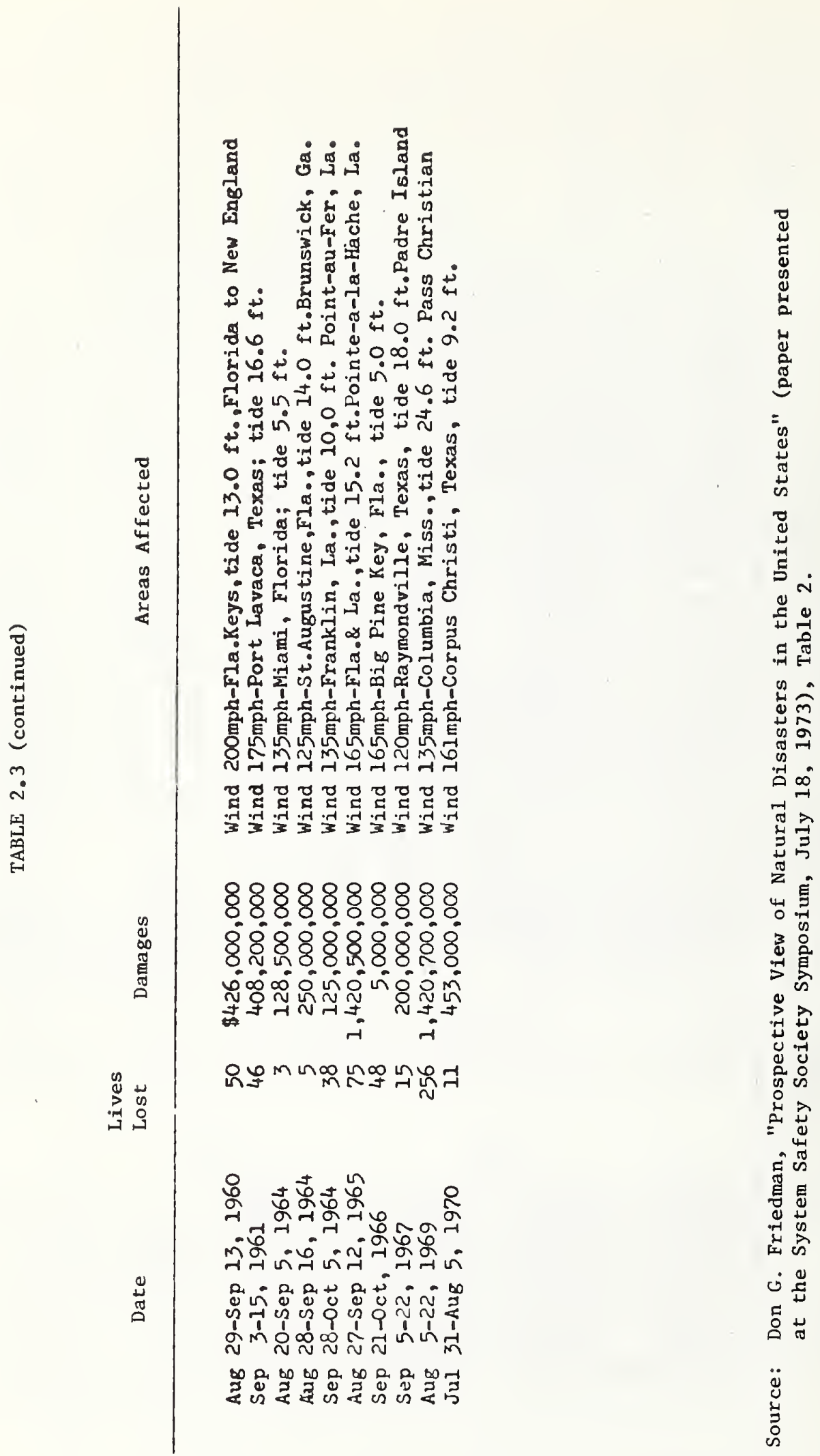




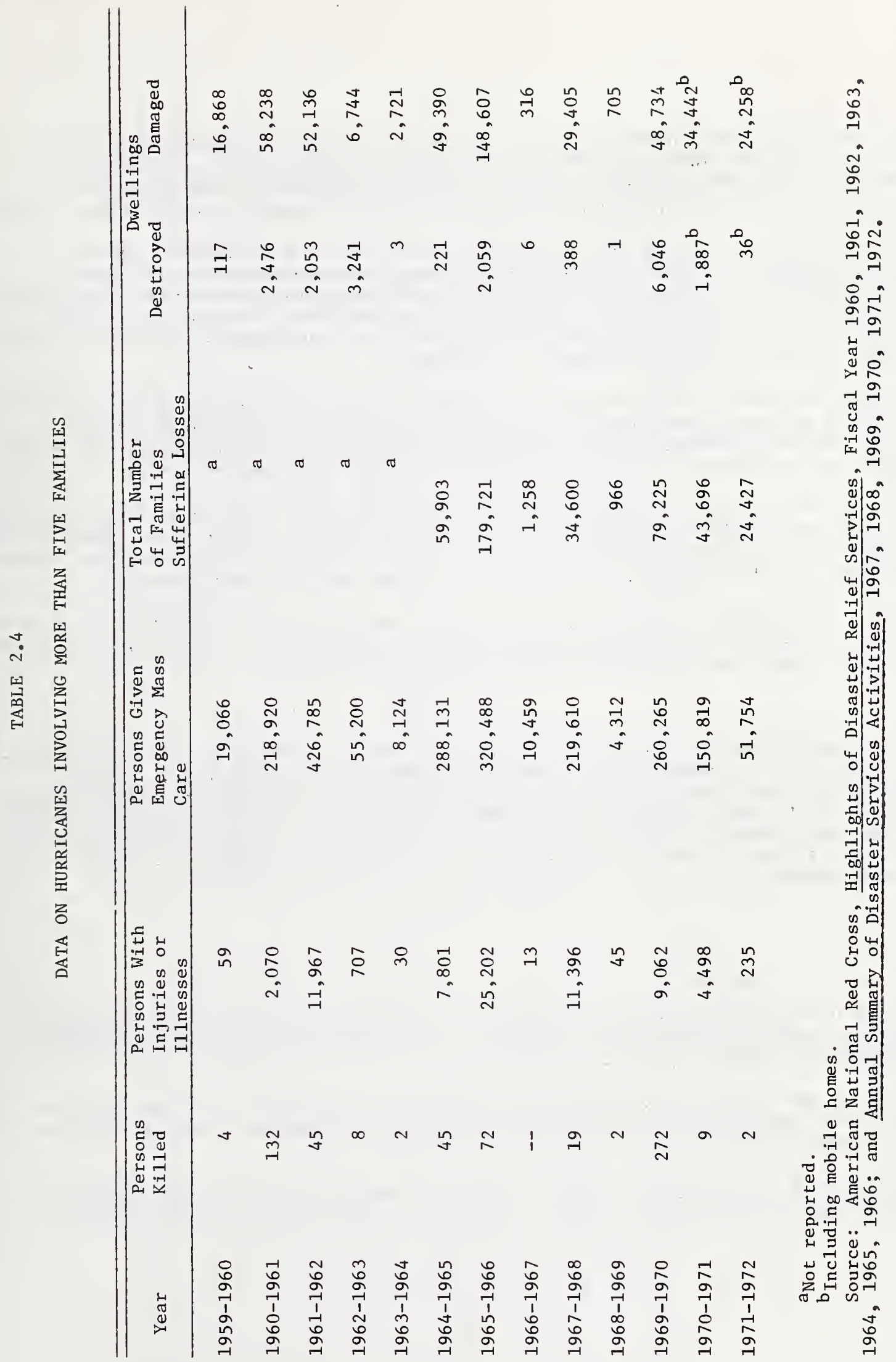


Dollar values are not reported for the destruction and damage to dwellings shown in Table 2.4 The destruction or damage to a dwelling involves many cost categories. In addition to the replacement costs of the home and belongings, there are costs in inconvenience and discomfort that families experience in relocation and temporary housing.

Unemployed resources that result from natural disasters are also economic losses. Table 2.5 includes the numbers of unemployed human resources related to the Agnes hurricane (1972) for seven states. Associated with the individual loss of income from unemployment is a decrease in tax revenues for the community. This occurs at a time when increased tax revenues are needed to meet the increased demand for public revenues stemming from post disaster restoration activities.

To relieve pressure on local and state contributions for recovery from national disasters, the Federal government provides aid through the President's Disaster Fund, Federal Disaster Assistance Administration. Table 2.5 indicates the amounts obligated from the Fund for the restoration of public facilities following the Agnes hurricane.

A study of the physical damage caused by Hurricane Agnes was conducted by Dun and Bradstreet. The study reported that the damage to business and ipdustry for Florida, Maryland, New York, Pennsylvania, and Virginia amounted to $\$ 600$ million. Since this figure excludes losses in production and sales, it can be considered an underestimate of total losses.

Table 2.6 lists some of the most destructive hurricanes in the United States for the period 1930-1972. Since 1965 the three most destructive hurricanes have caused nearly $\$ 6$ billion in damages; Agnes contributed more than $\$ 3$ billion of this total.

\subsection{Floods $^{2}$}

There are approximately 50 million acres of 1 and prone to flooding in the United States. ${ }^{3}$ The distribution of losses, however, varies geographically. Figure 2.3 divides the United States into 14 major river systems and indicates the distribution of flood losses by system for the period 1.925-1971. The total losses for the period amounted to $\$ 10.4$ billion. The Missouri, North Atlantic, Ohio, and Pacific river systems experienced the bulk ( $71 \%$ ) of flood losses. The Missouri river system alone accounted for nearly $25 \%$ of the total losses.

${ }^{1}$ Executive Office of the President, Office of Emergency Preparedness, The Federal Response to Tropical Storm Agnes, A Report to the Senate Subcommittee on Public Works, Subcommittee on Disaster Relief, May 1973, p. 6.

${ }^{2}$ It is not feasible in this report to separate flood losses into losses resulting from river floods, hurricanes, and other natural phenomena. Therefore, there will be some double-counting of losses from the previous section.

3 Executive office of the President, Office of Emergency Preparedness, Disaster Preparedness, Vol 3. (Washington, D.C.: Government Printing Office, January 1972), p。 7. 


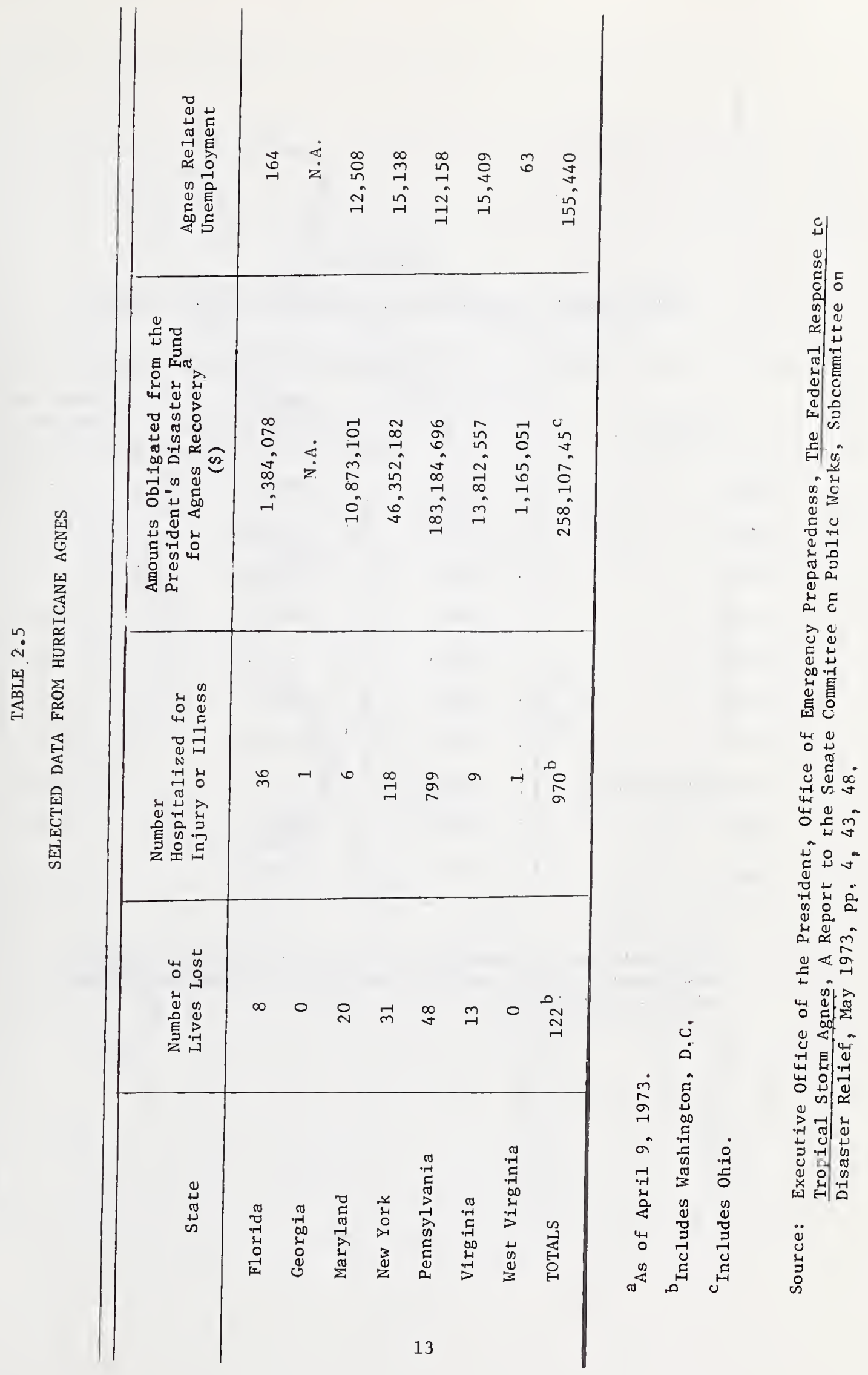


TABLE 2.6

MOST DESTRUCTIVE HURRICANES IN THE UNITED STATES, 1930-1972

\begin{tabular}{l|c|c|c}
\hline \multicolumn{1}{c|}{ Hurricane } & Year & $\begin{array}{c}\text { Damage } \\
(\$ 1,000,000)\end{array}$ & $\begin{array}{c}\text { Number of } \\
\text { Deaths }\end{array}$ \\
\hline Agnes & 1972 & $3,097.8$ & 117 \\
Camille & 1969 & $1,420.7$ & 258 \\
Betsy & 1965 & $1,420.5$ & 75 \\
Diane & 1955 & 831.7 & 184 \\
Carol & 1954 & 463.0 & 60 \\
Celia & 1970 & 453.8 & 11 \\
Carla & 1961 & 408.3 & 46 \\
New England Storm & 1938 & 387.1 & 600 \\
Donna & 1950 & 386.5 & 50 \\
Hazel & 1954 & 251.6 & 95 \\
\hline
\end{tabular}

Source: U.S. Department of Commerce, National Oceanic and Atmospheric Administration, Environmental Data Service, Climatological Data, National Summary 1972, Vol. 23, p. 62. 


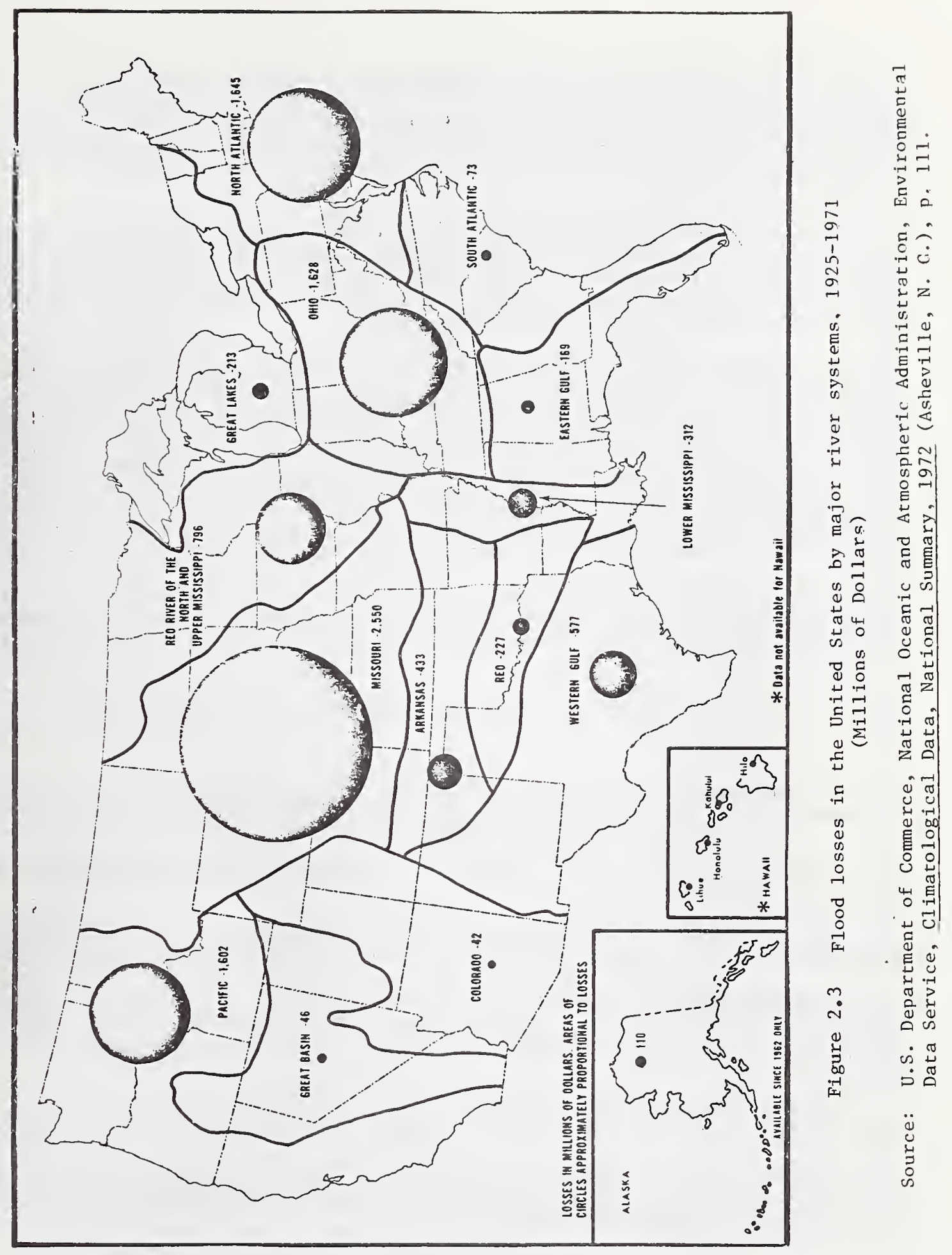


Total dollar losses for the period 1955-1971 were approximately $\$ 5.9$ billion. ${ }^{1}$ Table 2.7 apportions these losses to each state by year for the seventeen year period. Twice during this period the annual losses exceeded $\$ 900$ million; i.e., in 1955 losses totaled $\$ 995.5$ million and in 1969 losses totaled $\$ 900.7$ million. Figure 2.4 indicates the number of occurrences of floods and flash floods associated with each state's total dollar flood losses for 1955-1971.

In a 1957 cost-benefic analysis produced as a staff report by the Committee on Publig Works, it was hypothesized that the "potential average annual flood loss was $\$ 911$ million." In more recent years the estimated annual losses have been $\$ 1.5$ to $\$ 2.0$ billion. By the year 2020, annual flood losses are expected to be $\$ 5$ billion (disregarding any "major" improvements in the current state of flood protection).

The total number of lives lost and the amount of property damages resulting from floods are shown in Table 2.8 for five-year intervals, 1925-1969. For the period 1925-1971, the average monthly loss is shown in Table 2.9. The month of June has, on the average, produced the most severe losses ( 13 deaths and $\$ 34.8$ million in property damages). Average annual loss of lives for the forty-seven year period was 83. Property damages averaged $\$ 223.4$ million annually. By comparing the average annual property damages (Table 2.9) to each year's damages (Table 2.7) it is seen that during the five year interva1 1967-1971 the yearly damages exseeded the average annual damage for each year except 1970. The yearly loss for 1969 ( $\$ 900.6$ million) rose to four times the annual average loss ( $\$ 223.4 \mathrm{mi} 11$ ion)。

Losses due to floods are probably directly correlated to the population size of flood prone areas. The Natural Disaster Warning Survey Group has estimated that 10 million people occupy recognized $\mathrm{f} \frac{\mathrm{l}}{5} \mathrm{ood}$ plain areas and an additional 25 million are subject to the effects of nearby flooding.

Flash flooding is thought to affect 2,500 communities in the United States. ${ }^{6}$

${ }^{1}$ U.S. Department of Commerce, National Oceanic and Atmospheric Administration, Environmental Data Service, Climatological Data, National Summary, 1972, Vo1. 23, p. 114.

2 Douglas C. Dacy and Howard Kunreuther, The Economics of Natura1 Disasters (The Free Press: New York, 1969), p. 14.

${ }^{3}$ Executive Office of the President, Office of Emergency Preparedness, Disaster Preparedness, Vo1. 1 (Washington, D.C.: Government Printing Office, January 1972), p。15.

${ }^{4}$ National Waterways Conference, Inc., letter to Chief, OEP PL 91-606 Disaster Study Group, May 26, 1971; cited in Executive Office of the President, Office of Emergency Preparedness, Disaster Preparedness, Vo1. 1 (Washington, D.C.: Government Printing Office, January 1972); Po 15 .

${ }^{5}$ Executive Office of the President, Office of Emergency Preparedness, Disaster Preparedness, Vol. 3 (Washington, D.C.: Government Printing Office, January 1972), P. 8.

${ }^{6}$ U.S. Department of Commerce, National Oceanic and Atmospheric Administration, Office of Hydrology, A Plan for Improving the National River and Flood Forecast and Warning Service (Silver Spring, Md., 1969), p. 44. 


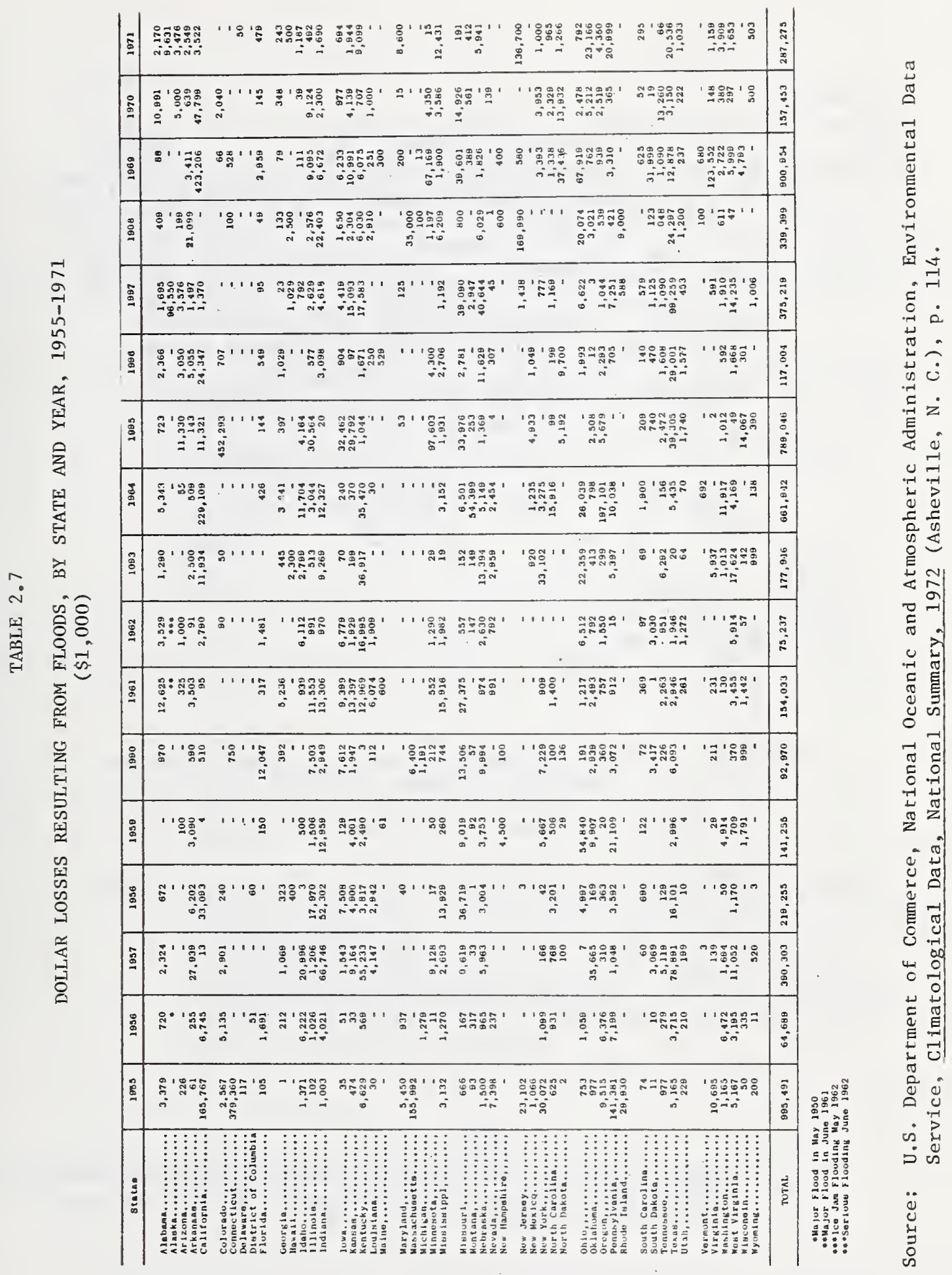




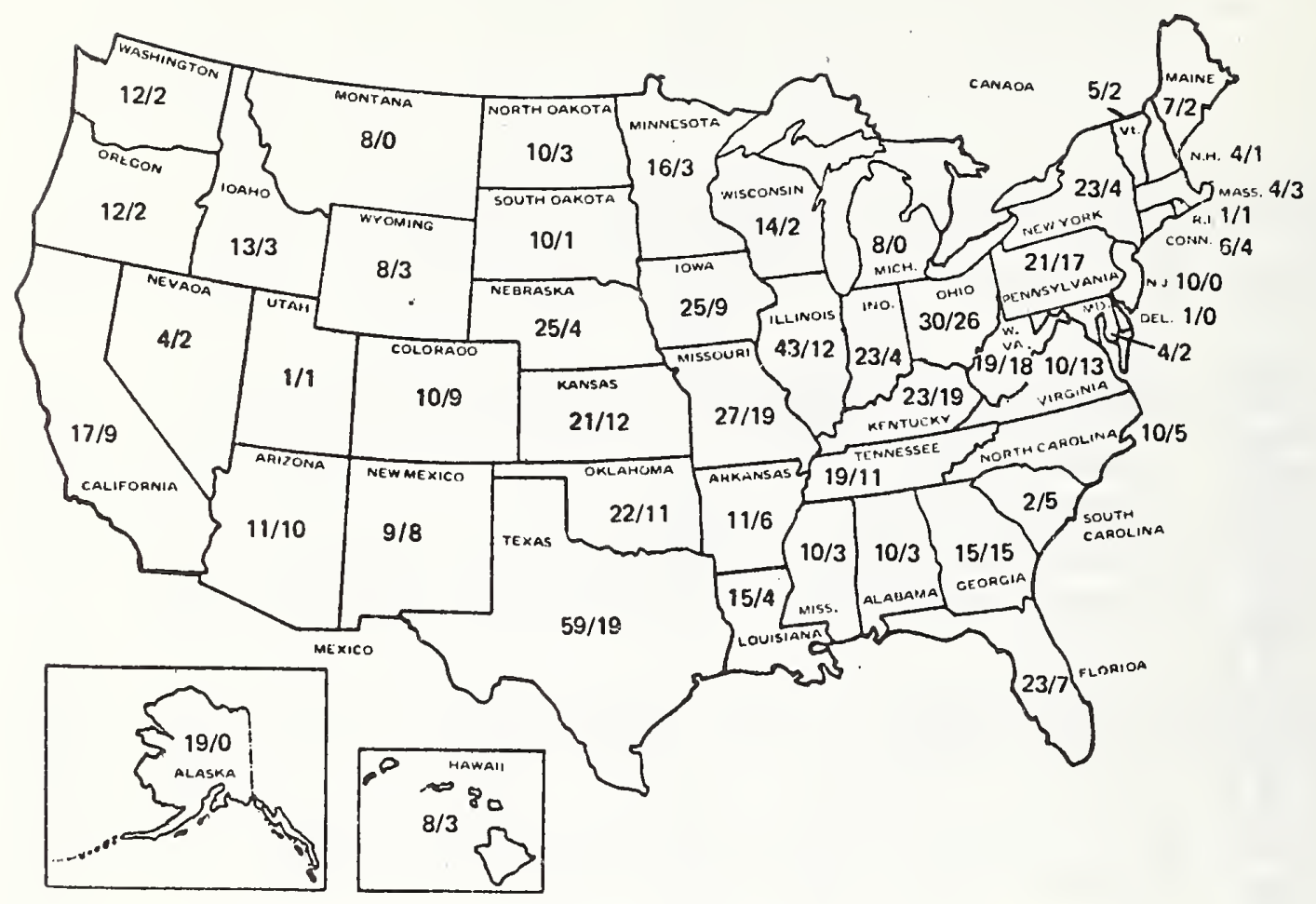

Figure 2.4 Number of floods resulting in assistance from the American Red Cross, 1955-1971

(Numbers with slash show "Floods/Flash Floods")

Source: Executive Office of the President, Office of Emergency Preparedness, Disaster Preparedness, Vo1. 3 (Washington, D.C.: Government Printing Office, January 1972), p. 7. 
TABLE 2.8

NUMBER OF LIVES LOST AND AMOUNT OF PROPERTY DAMAGES IN THE UNITED STATES

DUE TO FLOODS FOR FIVE-YEAR PERIODS, 1925-1969

Property Damages

Years

$(\$ 1,000,000 ' s)$
Number of

Lives Lost

$\begin{array}{lrl}1925-1929 & 495 & 579 \\ 1930-1934 & 76 & 146 \\ 1935-1939 & 966 & 783 \\ 1940-1944 & 481 & 315 \\ 1945-1949 & 133 & 304 \\ 1950-1954 & 1680 & 293 \\ 1955-1959 & 1695 & 498 \\ 1960-1964 & 1151 & 242 \\ 1965-1969 & 2520 & 239\end{array}$

Source: Douglas C. Dacy and Howard Kunreuther, The Economics of Natural

Disasters (New York: The Free Press, 1969), p. 6, 1925-1964;

Executive Office of the President, Office of Emergency Preparedness,

Disaster Preparedness, Vol. 3 (Washington, D.C.: Government

Printing Office, January 1972), p. 9; and American Red Cross, Highlights of Disaster Relief Services, Fiscal Year 1964-1965, 1965-1966 and Annual Summary of Disaster Services Activities, 1966-1967, 1967-1968, 1968-1969. 
TABLE 2.9

AVERAGE NUMBER OF LIVES LOST AND AMOUNT OF PROPERTY DAMAGES IN THE UNITED STATES DUE TO FLOODS, BY MONTH FOR THE PERIOD 1925-1971

\begin{tabular}{|c|c|c|}
\hline \multirow{2}{*}{ Month } & \multicolumn{2}{|c|}{ Average } \\
\hline & $\begin{array}{l}\text { Number of } \\
\text { Lives Lost }\end{array}$ & $\begin{array}{l}\text { Property Damages } \\
\quad(\$ 1,000)\end{array}$ \\
\hline January & 6 & 22,532 \\
\hline February & 3 & 6,723 \\
\hline March & 7 & 15,311 \\
\hline April & 11 & 31,929 \\
\hline May & 9 & 22,621 \\
\hline June & 13 & 34,858 \\
\hline July & 9 & 29,228 \\
\hline August & 11 & 25,017 \\
\hline September & 4 & 7,527 \\
\hline October & 3 & 5,655 \\
\hline November & 2 & 1,957 \\
\hline December & 5 & 20,045 \\
\hline Annual Average & 83 & 223,403 \\
\hline
\end{tabular}

Source: U.S. Department of Commerce, National Oceanic and Atmospheric Administration, Environmental Data Service, Climatological Data, National Summary, 1972 (Asheville, N. C.), p. 110. 
The losses generated by this type of flooding can be devastating。 For example, rains accompanying Hurricane Camille (1969) created flash floods in Virginia which resulted in the deaths of 150 persons and in property damages of $\$ 112$ million.

A historical account of the more severe river floods occurring in the United States is given by Table 2.10. The greatest property losses to date (1969) were produced by the KansasMissouri flood of 1951. Damages amounted to $\$ 923.2$ million.

A detailed account of the resultant losses from a more recent flood (Agnes, 1972) is given in Table 2.11. Damages to public and private property amounted to nearly $\$ 1.5$ billion。 Combined with $\$ 601.2$ million of damages to business and industry (not shown in Table 2.11 ), Agnes floods produced a total $\$ 2.1$ billion in damages. ${ }^{2}$ These damages are $120 \%$ greater than the Kansas-Missouri floods of 1951.

It also happens that the communities surrounding a disaster area are affected in several ways. For example, the Black Hills flood (1972) affected tourism and tax revenues of nearby communities that were virtually untouched by the flood itself. Flooding did not occur in the town of Wa11, South Dakota, but Wall did experience a decline ${ }_{3}$ in tourism and a decrease of $\$ 50,000$ in sales tax revenues for the third quarter of 1972. For a four county area, a loss of $\$ 455,000$ in tax revenues was reported. ${ }^{4}$ Further estimates indicate a total decrease of $\$ 2$ billion in sales tax revenues during the second and third quarters for the four counties. 5

An account of the non-pecuniary losses resulting from floods and flash floods are given in Table 2.12 for fiscal years 1960-1973. The effects of the Agnes floods can be seen in the data for fiscal year 1972. A total of 519 persons were killed in that year; more than 156,000 families suffered losses; 7,346 dwellings were destroyed and 133,803 were damaged. A record number of persons were also injured or $i 11(16,587)$ and were given emergency mass care $(604,071)$ that year.

\subsection{Earthquakes}

It has been said that earthquakes present the "greatest potential for catastrophic--even cataclysmic--losses in concentrated urban areas." movements but additional losses result from earthquake produced fires, floods, landslides

${ }^{1}$ Executive Office of the President, Office of Emergency Preparedness, Disaster Preparedness, Vo1. 1 (Washington, D.C.: Government Printing Office, January 1972), p. 25.

2 Executive Office of the President, Office of Emergency Preparedness, The Federal Response to Tropica1 Storm Agnes (Washington, D.C.: Government Printing Office, May 1973), pp. 6-8.

${ }^{3}$ U.S. Congress, Senate, Committee on Public Works, To Investigate the Adequacy and Effectiveness of Federal Disaster Relief Legislation, Part 2, Hearings, before the 93rd Cong., 1st sess., March 30 and 31,1973, p. 340.

4 Ibid., p. 341 .

5

Ibid.,

${ }^{6}$ U.S. Department of Housing and Urban Development, Federa1 Insurance Administration, Report on Earthquake Insurance to the Congress of the United States. Pursuant to Section Five of the Southeast Hurricane Disaster Relief Act of 1965 (Washington, D.C. 1971), p. 8. 
TABLE 2.10

SEVERE RIVER FLOOD DISASTERS IN THE UNITED STATES, 1935-1969

\begin{tabular}{|c|c|c|c|c|}
\hline Year & Month & Location & $\begin{array}{l}\text { Number } \\
\text { of Lives } \\
\text { Lost }\end{array}$ & $\begin{array}{c}\text { Property } \\
\text { Damages } \\
(\$ 1,000,000)\end{array}$ \\
\hline \multirow[t]{2}{*}{1935} & May-July & Republican and Kansas Rivers & 110 & 18.0 \\
\hline & July & Upper Susquehanna & 52 & 26.0 \\
\hline 1936 & March-April & Eastern United States & 107 & 270.0 \\
\hline 1937 & Jan.Feb. & Ohio and Lower Mississippi River Basins & 137 & 417.7 \\
\hline 1938 & March & Southern California & 79 & 24.5 \\
\hline 1939 & July & Licking and Kentucky Rivers & 78 & 1.7 \\
\hline 1940 & August & $\begin{array}{l}\text { Southern Virgiria and Carolinas, and } \\
\text { Eastern Tennessee }\end{array}$ & 40 & 12.0 \\
\hline 1943 & April-June & $\begin{array}{l}\text { Maumee, Wabash, Upper Mississippi, } \\
\text { Missouri, White, and Arkansas River Basins }\end{array}$ & 60 & 172.0 \\
\hline 1947 & May-July & $\begin{array}{l}\text { Lower Missouri and Middle Mississippi } \\
\text { River Basins }\end{array}$ & 29 & 235.0 \\
\hline 1948 & May-June & Columbia Basin & 35 & 101.7 \\
\hline 1950 & June & Central West Virginia & 31 & 4.0 \\
\hline 1951 & June-July & Kansas-Missouri & 28 & 923.2 \\
\hline \multirow[t]{2}{*}{1955} & August & Hurricane floods in Northeast & 187 & 714.1 \\
\hline & December & West Coast & 61 & 154.5 \\
\hline 1963 & March & Ohio River Basin & 26 & 97.6 \\
\hline \multirow[t]{2}{*}{1964} & June & Montana & 31 & 54.3 \\
\hline & December & California and Oregon & 40 & 415.8 \\
\hline 1965 & June & Sanderson, Texas, flash flood & 26 & 2.7 \\
\hline \multirow[t]{3}{*}{1969} & Jan.-Feb. & California & 60 & 399.2 \\
\hline & July & Northern Ohio & 30 & 87.9 \\
\hline & August & James River Basin in Virginia & 154 & 116.0 \\
\hline
\end{tabular}

Source: Executive Office of the President, Office of Emergency Preparedness, Disaster Preparedness, Vol. 3 (Washington, D.C., Government Printing Office, January 1972), p. 8. 


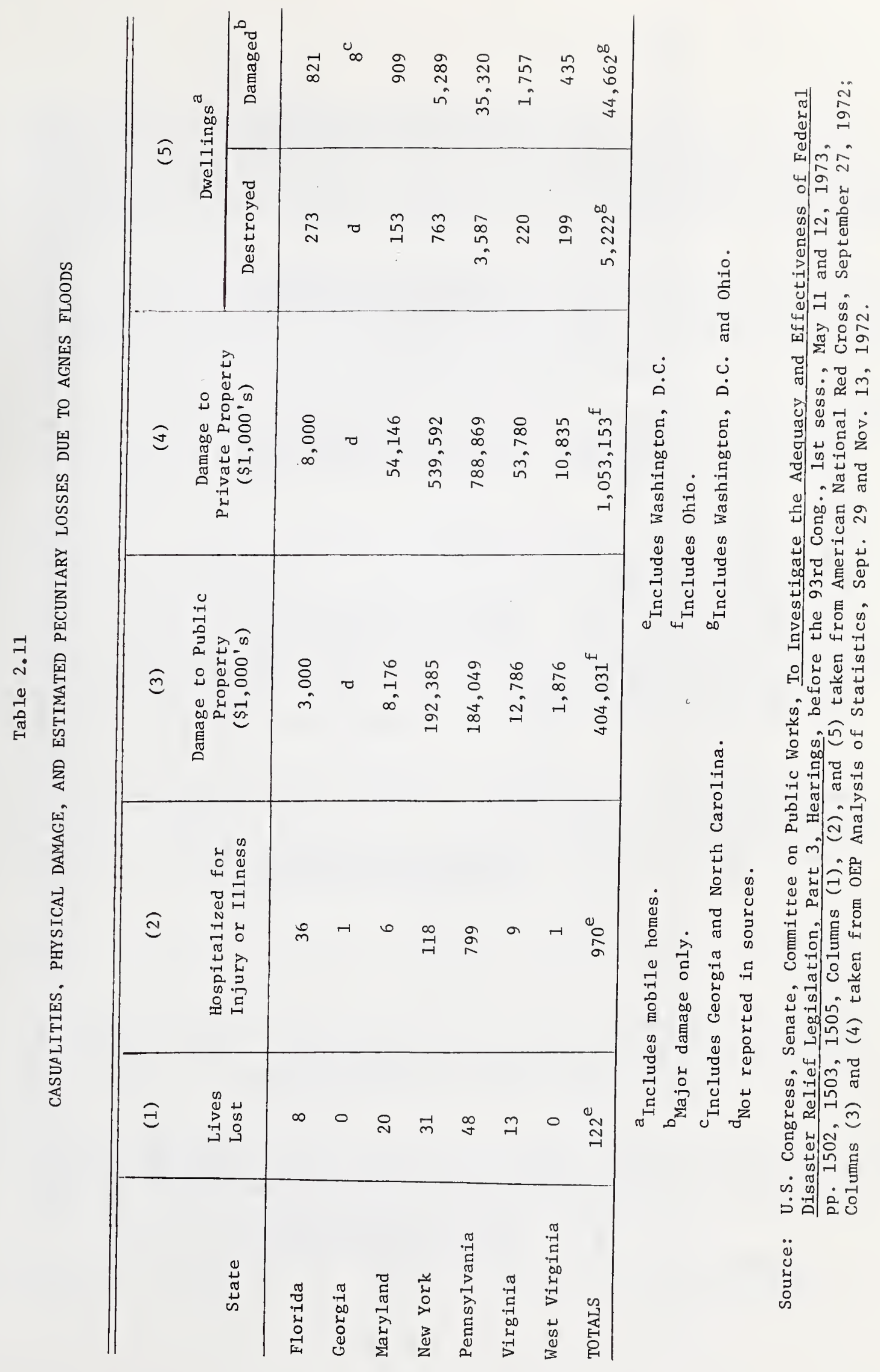




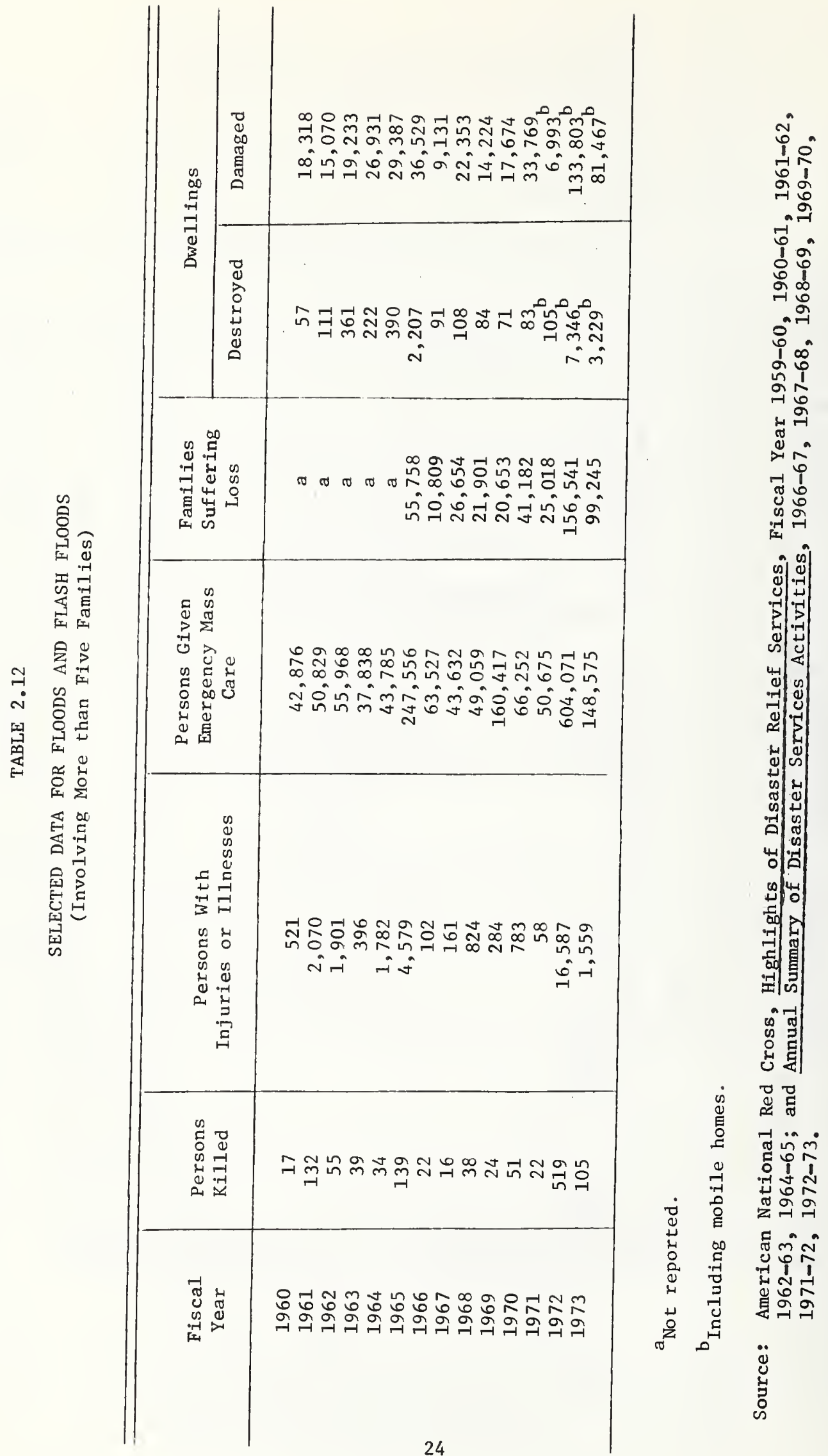


and tsunamis. ${ }^{1}$ Since 1865, major earthquakes in the United States have produced $\$ 1.86$ billion in property damages (Table 2.13). Since 1811, earthquakes have accounted for more than 1,660 deaths. The San Francisco earthquake of 1906 caused $\$ 524$ million dollars in property damages ( $\$ 500$ million attributed to fire loss). Estimated damages resulting from the Alaska earthquake of 1964 amounted to $\$ 500$ million. In the 1971 San Fernando earthquake, damages totaled $\$ 553$ million.

Without some form of protection, damages are likely to be even greater in the future than in the past if earthquakes continue to occur with the same frequency and intensity, because positive population growth rates and economic development increase potential losses. For example, the damages to dwellings resulting from another earthquake in San Francisco of the same intensity as the one in 1906 have been estimated at $\$ 25$ billion.

The intensities of earthquakes and the damages produced provide a basis for the construction of a seismic risk map as shown in Figure 2.5. Risk zones may vary from 0 , no damage, to 3 , major damage. The figure shows that parts of Washington, Utah, Idaho, Montana, South Carolina, the Northeast, the South Central states, and a major portion of California are subject to high seismic risk.

The location and intensity of earthquakes occurring in the United States through 1966 is shown in Figure 2.6. A sma11 dot (b) indicates where the intensity was strong enough to affect more than 25,000 square miles; a large dot (a) indicates where the intensity was strong enough to affect more than 150,000 square miles or to cause damages ranging from several thousand to $\$ 100,000$; a small encircled dot, $Q$, indicates where intensity was strong enough to affect more than 500,000 square miles or to cause damages of $\$ 100,000$ to $\$ 1,000,000$; and a large encircled dot, (1) indicates where the intensity was strong enough to affect more than 1 million square miles or to cause damages greater than $\$ 1,000,000$. Although California has experienced the majority of earthquakes, the figure shows that earthquakes have occurred throughout the United States.

The record of lives lost and property damages due to earthquakes for five-year intervals is shown in Table 2.14. Over the 41 year period from 1925-1965, a total of 318 lives were lost and property was damaged in the amount of $\$ 592$ million. During the 1960-1964 period $68 \%$ ( $\$ 405$ million) of the total property damages occurred and $36 \%$ (115) of the total number of lives were lost. Another source reports that the Algska earthquake of 1964 alone caused $\$ 500$ million in property damages and 131 deaths。

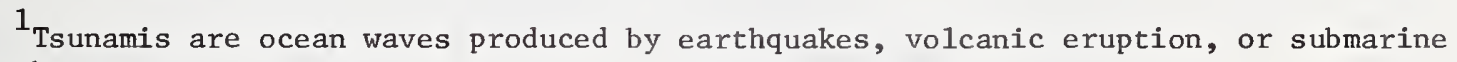
disturbances.

${ }^{2}$ U.S. Department of Housing and Urban Development, Federal Insurance Administration, Report on Earthquake Insurance to the Congress of the United States, Pursuant to Section Five of the Southeast Hurricane Disaster Relief Act of 1965 (Washington, D.C. 1971), p. 8 .

3

Ibid.

${ }^{4}$ U.S. Department of Commerce, Environmental Science Services Administration, Coast and Geodetic Survey, A Preliminary Study of Engineering Seismology Benefits, by Joseph D. Crumlish and George F. Wirth (Washington, D.C.: Government Printing Office, August 1967), p. 7.

5 Executive Office of the President, Office of Emergency Preparedness, Disaster Preparedness, Vo1. 1 (Washington, D.C.: Government Printing Office, January 1972), p. 73. 
PROPERTY DAMAGES RESULTING FROM MAJOR U.S. EARTHQUAKES, 1865-1971

$(\$ 1,000,000)$

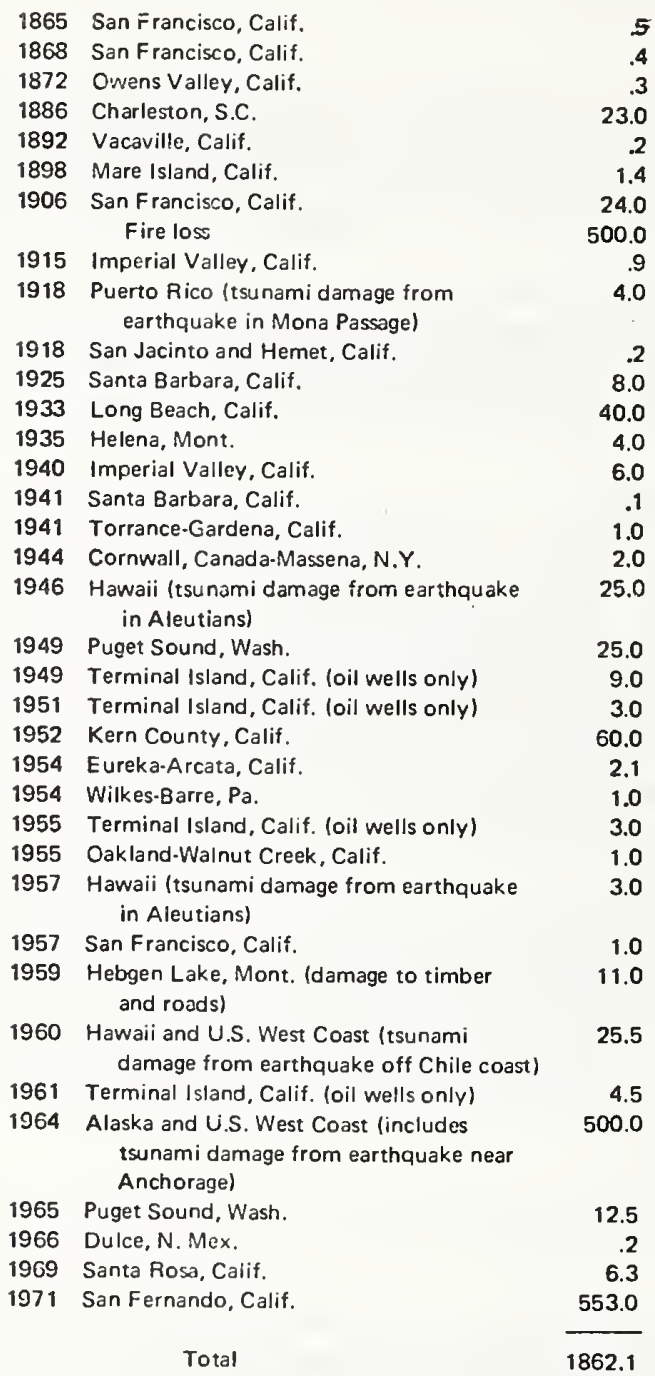

Source: Executive Office of the President, Office of Emergency Preparedness, Disaster Preparedness, Vol. 3 (Washington, D.C.: Government Printing Office, January 1972), p. 82. 


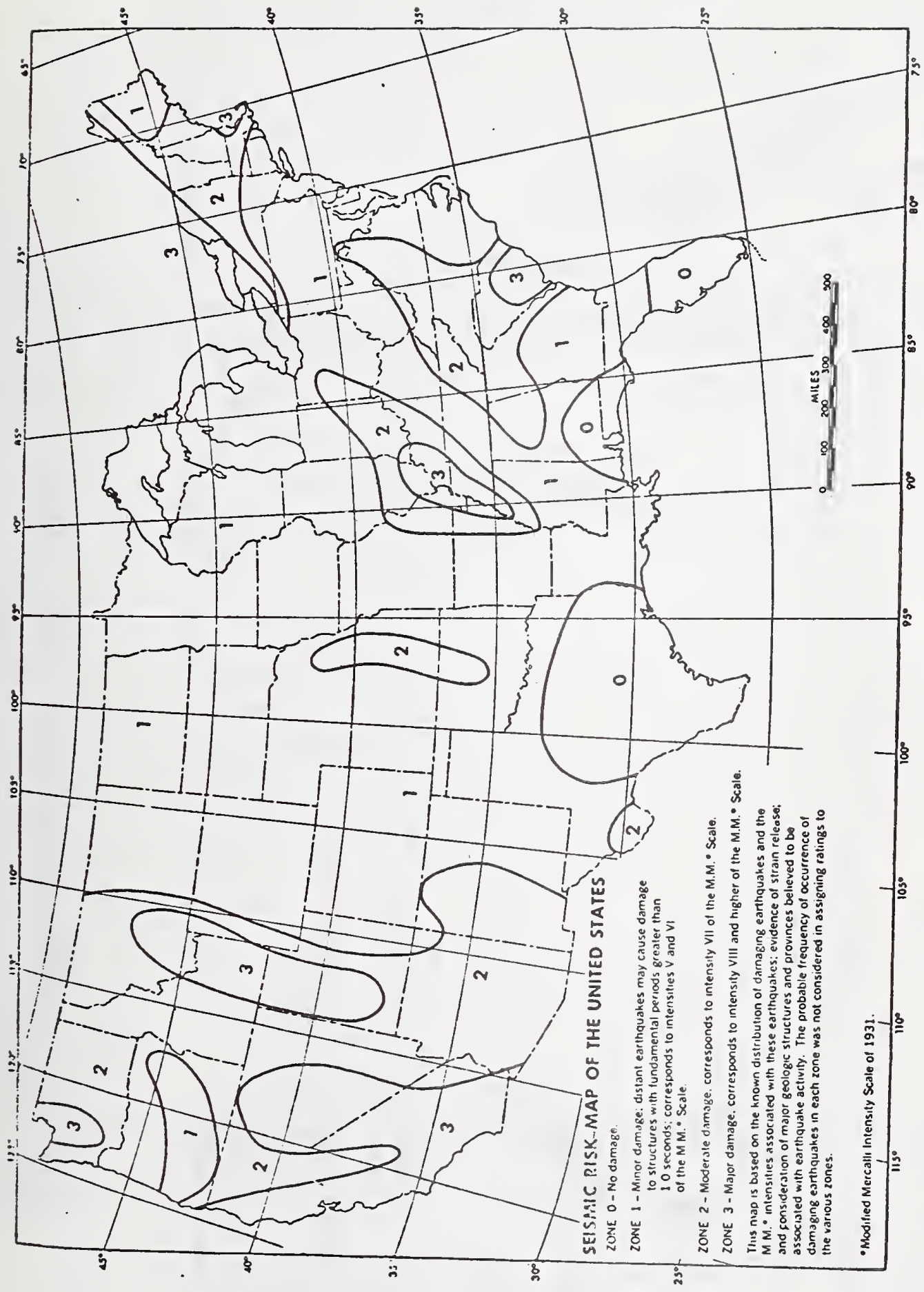

ษั口

टิ

누

फ "⿹्त

응 는

들 ट्ञ

०ै क

3 o 14

है त

늠

舟官

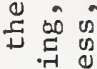

㟧出

क ट्ष

क.

क त्ञ

4 व

บ Uั

可

पू

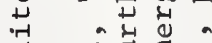

ธขึ界界

( ) गु

岃 竹

出 부ㅇㅛㅛ

0. 品息出焉

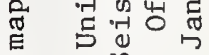

क ऽ ट

年 D出

.

0.- 0 .

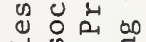

苛 क

司点

थ है

ก ख

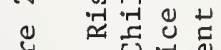

$\Rightarrow$ U

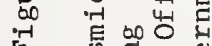

मा कि वृ

w व

त 3

टี

on 되 红 $\dot{a}$

岂䒕

过告

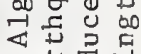

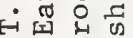

i 50

نூ 


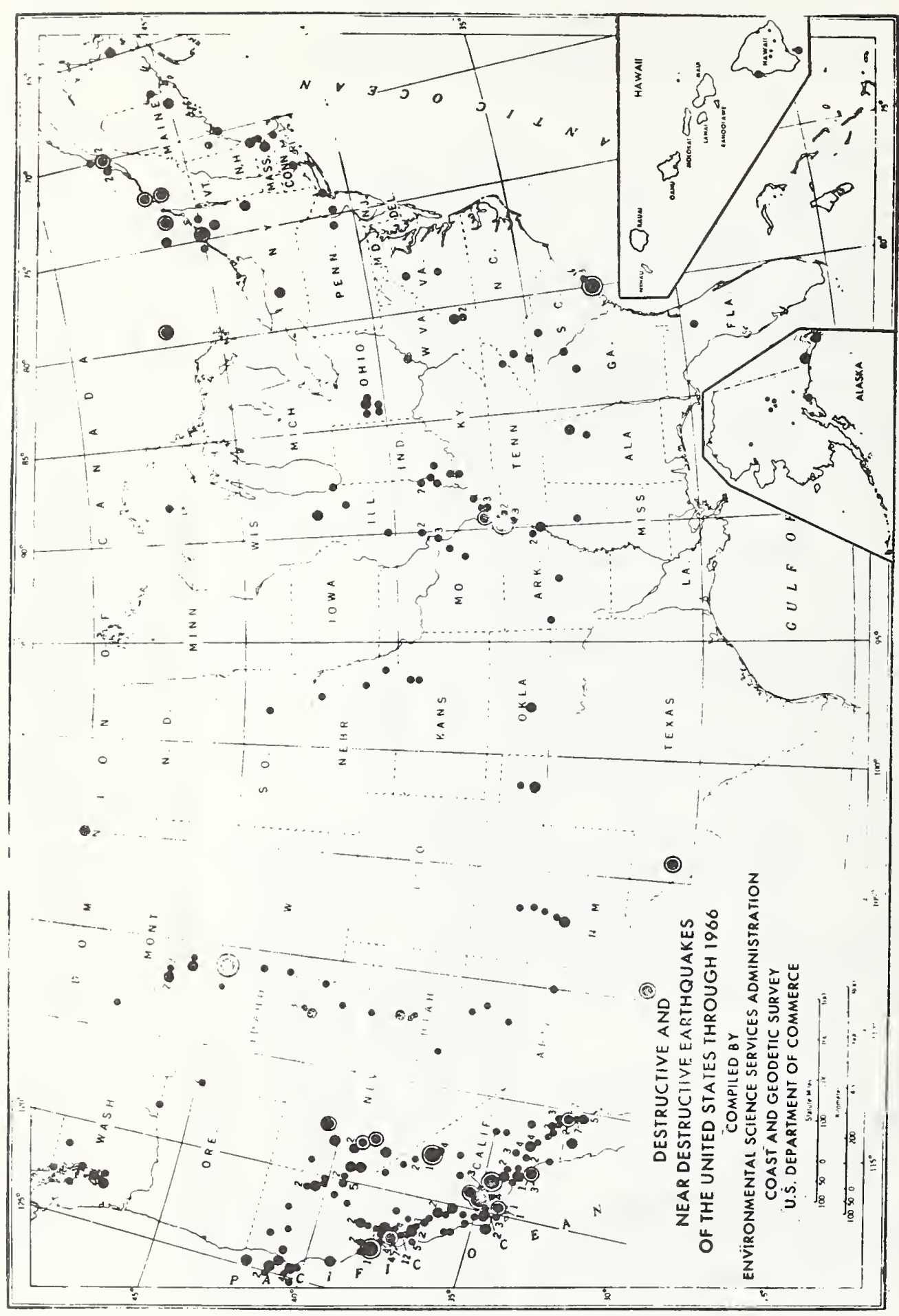


TABLE 2.14

LIVES LOST AND VALUE OF PROPERTY DAMAGES IN THE UNITED STATES

DUE TO EARTHQUAKES FROM 1925-1964 BY FIVE-YEAR PERIODS, AND FOR 1965

\begin{tabular}{c|c|c}
\hline Years & $\begin{array}{c}\text { Value of } \\
\text { Property Damages } \\
\text { (In Millions of Dollars) }\end{array}$ & Lives Lost \\
\hline $1925-1929$ & 8 & 13 \\
$1930-1934$ & 40 & 117 \\
$1935-1939$ & 4 & 4 \\
$1940-1944$ & 7 & 9 \\
$1945-1949$ & 34 & 8 \\
$1950-1954$ & 65 & 15 \\
$1955-1959$ & 16 & 34 \\
$1960-1964$ & 405 & 115 \\
1965 & 13 & 392 \\
\hline
\end{tabular}

Source: Douglas C. Dacy and Howard Kunreuther, The Economics of Natural Disasters

(New York: The Free Press, 1969), p. 6. 
Table 2.15 lists the casualities, families affected, and physical damages to dwellings and small businesses as a result of five severe earthquakes that occurred between 1959 and 1971 . The San Fernando earthquake caused only about half the number of deaths as the Alaska earthquake, but more than 21 times the destruction and damage to dwellings. It should be noted, however, that the San Fernando earthquake recorded a magnitude of 6.6 on the Richter scale, while the Alaska earthquake recorded a magnitude of approximately 8.5 .1 Thus, the magnitude of an earthquake, as measured on the Richter scale, is not the sole indicator of damage of an earthquake. Total damages, for example, are obviously related to population density。

Tables 2.16 and 2.17 give more detailed information of the losses caused by the Alaska and San Fernando earthquakes. Table 2.16 shows damages of $\$ 71.2$ million to Federal facilities alone from the Alaska earthquake. The losses due to the San Fernando earthquake, Table 2.17, are broken down into public and private sector losses. Dollar losses were shared about equally for each sector with the private and public sectors incurring $52 \%$ ( $\$ 259$ million) and $48 \%$ ( $\$ 238$ million), respectively.

\subsection{Tornadoes}

Tornadoegs have caused the loss of more lives than any other natural disaster in the United States. Over a 57 year period, 1916-1972, tornadoes took the lives of 10,500 persons, resulting in an annual average of 184 deaths (Table 2.18). For the last 15 years, however, Table 2.18 shows that the annual death toll has remained below the average (184 deaths) with the exception gf 1965. Since 1953, the annual average number of deaths due to tornadoes has decreased $42 \%$ The decrease can be attributed to advancements in a national warning system.

Table 2.18 also shows that for the past 8 years the United States has experienced annual tornado property losses of $\$ 50$ million and more (category 8 ). For the last 31 years annual losses have exceeded $\$ 5$ million (category 7). These current dollar losses represent conservative estimates and in effect serve as a lower bound to annual property losses. The usefulness of Table 2.18 may be found more in the frequency of tornadoes reported in various categories. Each of 11 tornadoes in 1965 caused property damages of $\$ 5$ million and over (category 7 and over). During 1970 there were 6 such tornadoes and in 1971 there were 5. Tornadoes occur in all 50 states. $^{5}$ Figure 2.7 shows the incidence by state for

$1_{1}$

${ }^{1}$ Executive Office of the President, Office of Emergency Preparedness, Disaster Preparedness, Vo1. 1 (Washington, D.C.: Government Printing Office, January 1972), p. 73.

2 Ibid., p. 35.

3

Ibid.

4

${ }^{4}$ Ibid.

${ }^{5}$ U.S. Department of Commerce, National Oceanic and Atmospheric Administration, National Weather Service, Tornado Preparedness Planning (Washington, D.C.: Government Printing Office, October 1970), p. 24. 


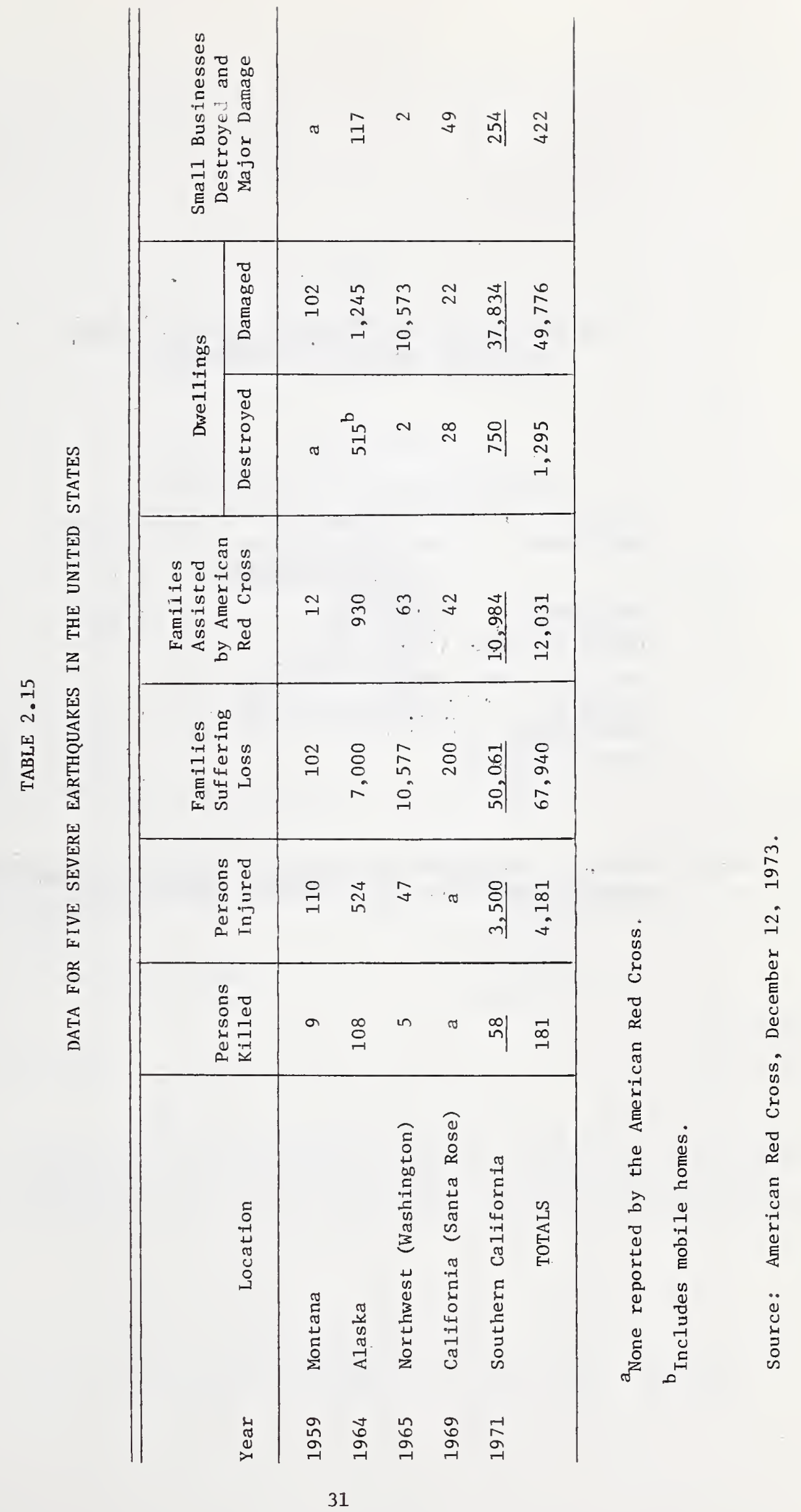


TABLE 2.16

\section{ESTIMATED DAMAGES TO FEDERAL FACILITIES IN ALASKA RESULTING FROM THE 1964 EARTHQUAKE}

Federal Agency

Dept. of Defense

Dept. of Interior

Dept. of Commerce

Federal Aviation Agency

Dept. of Health, Education, and Welfarc

General Services

Administration

TOTAL
Primary Loss

Barracks and other facilities at Fort Richardson, Elmendorf

Air Force Base, and Kodiak

Naval Station

Alaska Railroad

Damaged facilities

Facilities at Anchorage

International Airport

Public Health Service, Native

Hospital

Office supplies and equipment

Estimased Damage (SMilliun)

35.6

31.5

1.8

1.3

.6

.4

71.2

Source: Douglas C. Dacy and Howard Kunreuther, The Economics of Natural Disasters (New York: The Free Press, 1969), p. 126. 
TABLE 2.17

LOSSES DUE TO THE SAN FERNANDO EARTHQUAKE BY PRIVATE AND PUBLIC SECTOR

Private Sector:

Buildings, excluding land and contents:

Los Angeles City

San Fernando City

$\$ 170,300,000$

$35,500,000$

Elsewhere

Non-building structures, excluding land

$18,500,000$

$35,000,000$

TOTAL

Public Sector:

Los Angeles City

San Fernando City

Los Angeles County

Other local jurisdictions

Porter Ranch (aftershock damage)

Utilities

TOTAL

$103,300,000$

200,000

$100,000,000$

$5,000,000$

$8,000,000$

$22,000,000$

$238,500,000$

GRAND TOTAL

Source: U.S. Department of Commerce, National Oceanic and Atmospheric Administration, Environmental Research Laboratories, A Study of Earthquake Losses in the San Francisco Bay Area, A Report Prepared for the Office of Emergency Preparedness, Part B, p. 17. 
TABLE 2.18

FREQUENCY OF TORNADOES, RESULTING CASUALITTES, AND PROPERTY LOSSES, 1916-1972

\begin{tabular}{|c|c|c|c|c|c|c|c|c|}
\hline \multirow{2}{*}{ YEAR } & \multirow{2}{*}{$\begin{array}{l}\text { Number } \\
\text { Tornadoes }\end{array}$} & \multirow{2}{*}{$\begin{array}{l}\text { Tornado } \\
\text { Days }\end{array}$} & \multirow{2}{*}{$\begin{array}{l}\text { Total } \\
\text { Deaths }\end{array}$} & \multirow{2}{*}{$\begin{array}{l}\text { Most Deaths } \\
\text { in Sirngle } \\
\text { Tornado }\end{array}$} & \multirow{2}{*}{ 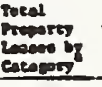 } & \multicolumn{3}{|c|}{ nequecer of somudoes or eirecons ${ }^{\circ}$} \\
\hline & & & & & & $\begin{array}{c}\text { Category } \\
5 \\
\end{array}$ & $\begin{array}{c}\text { Catemory } \\
6\end{array}$ & $\begin{array}{l}\text { Cotegory } \\
7 \text { and Oar }\end{array}$ \\
\hline 1916 & 90 & 36 & 150 & 30 & 6 & 7 & 1 & 0 \\
\hline 1917 & $12 \mathrm{I}$ & 38 & 509 & 101 & 7 & 21 & 9 & .0 \\
\hline 1918 & 81 & 45 & 135 & 36 & 7 & 20 & 5 & 0 \\
\hline 1919 & 64 & 35 & 206 & 59 & 7 & 10 & 2 & 0 \\
\hline 1920 & 87 & 50 & 498 & 87 & 7 & 14 & 10 & 0 \\
\hline 1921 & 105 & 55 & 202 & 61 & 7 & 22 & 3 & 0 \\
\hline 1922 & 108 & 64 & 135 & 16 & 7 & 27 & 5 & 0 \\
\hline 1923 & 102 & 59 & 109 & 23 & 6 & 21 & 1 & 0 \\
\hline 1924 & 330 & 57 & 376 & 85 & 7 & 26 & 11 & 1 \\
\hline 1925 & 119 & 65 & 794 & 689 & 7 & 34 & 2 & 1 \\
\hline 1926 & 111 & 57 & 144 & 23 & 6 & 28 & 0 & 0 \\
\hline 1927 & 163 & 62 & 540 & 92 & 7 & 42 & 9 & 1 \\
\hline 1928 & 203 & 79 & 92 & 14 & 7 & 40 & 7 & 0 \\
\hline 1929 & 197 & 74 & 274 & 40 & 7 & 48 & 4 & 0 \\
\hline 1930 & 192 & 72 & 179 & 41 & 7 & 38 & 6 & 0 \\
\hline 1931 & 94 & 57 & 36 & 6 & 6 & 14. & 1 & 0 \\
\hline 1932 & 151 & 67 & 394 & 37 & 7 & 23 & 1 & 1 \\
\hline 1933 & 258 & 96 & 362 & 34 & 7 & 46 & 9 & 0 \\
\hline 1934 & 147 & 77 & 47 & 6 & 6 & 10 & 3 & 0 \\
\hline 1935 & 180 & 77 & 70 & 11 & 6 & 25 & 0 & 0 \\
\hline 1936 & 151 & 71 & 552 & 216 & 7 & 17 & 5 & 1 \\
\hline 1937 & 147 & 75 & 29 & 5 & 6 & 24 & 0 & 0 \\
\hline 1938 & 213 & 76 & 183 & 32 & 7 & 29 & 6 & 0 \\
\hline 1939 & 152 & 75 & 87 & 27 & 7 & 21 & 3 & 0 \\
\hline 1940 & 124 & 62 & 65 & 18 & 7 & 13 & 2 & 0 \\
\hline 1941 & 118 & 57 & 53 & 25 & 6 & 24 & 1 & 0 \\
\hline 1942 & 167 & 66 & 384 & 65 & 7 & 42 & 10 & 0 \\
\hline 1943 & 152 & 61 & 58 & 5 & 7 & 28 & 8 & 0 \\
\hline 1944 & 169 & 68 & 275 & 100 & 7 & 50 & 9 & 0 \\
\hline 1945 & 121 & 66 & 210 & $69^{\circ}$ & 7 & 21 & 10 & 1 \\
\hline 1946 & 106 & 65 & 78 & 15 & 7 & 29 & 7 & 0 \\
\hline 1947 & 165 & 78 & 313 & 169 & 7 & 46 & 7 & 1 \\
\hline 1948 & 183 & 68 & 140 & 33 & 7 & 62 & 11 & 2 \\
\hline 1949 & 249 & 80 & 212 & 58 & 7 & 54 & 13 & 0 \\
\hline 1950 & 199 & 88 & 70 & 18 & 7 & 47 & 9 & 0 \\
\hline 1951 & 272 & 113 & 34 & 6 & 7 & 35 & 11 & 2 \\
\hline 1952 & 236 & 98 & 230 & 57 & 7 & 53 & 19 & 0 \\
\hline 1953 & 437 & 136 & 516 & 116 & 8 & 63 & 18 & 7 \\
\hline 1954 & 549 & 159 & 35 & 6 & 7 & 63 & 8 & 1 \\
\hline 1955 & 593 & 153 & 125 & 80 & 7 & 74 & 13 & 1 \\
\hline 1956 & 532 & 155 & 83 & 25 & 7 & 83 & 24 & 1 \\
\hline 1957 & 864 & 154 & 191 & 44 & 8 & 129 & 26 & 3 \\
\hline 1958 & 565 & 166 & 66 & 19 & 7 & 70 & 8 & 1 \\
\hline 1959 & 589 & 156 & 58 & 21 & 7 & 70 & 4 & 1 \\
\hline 1960 & 618 & 172 & 47 & 16 & 7 & 65 & 11 & 1 \\
\hline 1961 & 682 & 169 & S1 & 16 & 7 & 103 & 21 & 1 \\
\hline 1962 & 658 & 152 & 28 & 17 & 7 & 51 & 10 & 0 \\
\hline 1963 & 461 & 141 & 31 & 5 & 7 & 77 & 15 & 1 \\
\hline 1964 & 713 & 156 & 73 & 22 & 7 & 113 & 17 & 5 \\
\hline 1965 & 899 & 181 & 298 & 44 & 8 & 126 & 30 & 11 \\
\hline 1966 & 570 & 150 & 99 & 58 & 8 & 79 & 13 & 4 \\
\hline 1967 & 912 & 173 & 116 & 33 & 8 & 125 & 33 & 8 \\
\hline 1968 & 661 & 171 & 131 & 34 & 8 & 82 & 26 & $c$ \\
\hline 1969 & 604 & 155 & 66 & 32 & 8 & 98 & 16 & 3 \\
\hline 1970 & 649 & 171 & 73 & 26 & 8 & 97 & 24 & 6 \\
\hline 1971 & 888 & 192 & 156 & 58 & 8 & 71 & 30 & 5 \\
\hline 1972 & 741 & 194 & 27 & 6 & 8 & 100 & 28 & 1 \\
\hline leans: & & & & & & & & \\
\hline $953-72$ & 659 & 163 & 114 & $\cdots$ & $\cdots$ & 87 & 19 & 3 \\
\hline
\end{tabular}

NORE: -- The above estimated losses are based on values at time of occurrence.

Astorm damages in categories:

5. $\$ 50,000$ to $\$ 500,000 \quad$ 7. $\$ 5$ million to $\$ 50$ million

6. $\$ 500,000$ to $\$ 5$ million 8 . $\$ 50$ million and over.

Source: Executive Office of the President, Office of Emergency Preparedness, Disaster Preparedness, Vo1. 3 (Washington, D. C., Government Printing Office, January 1972), p. 30. 


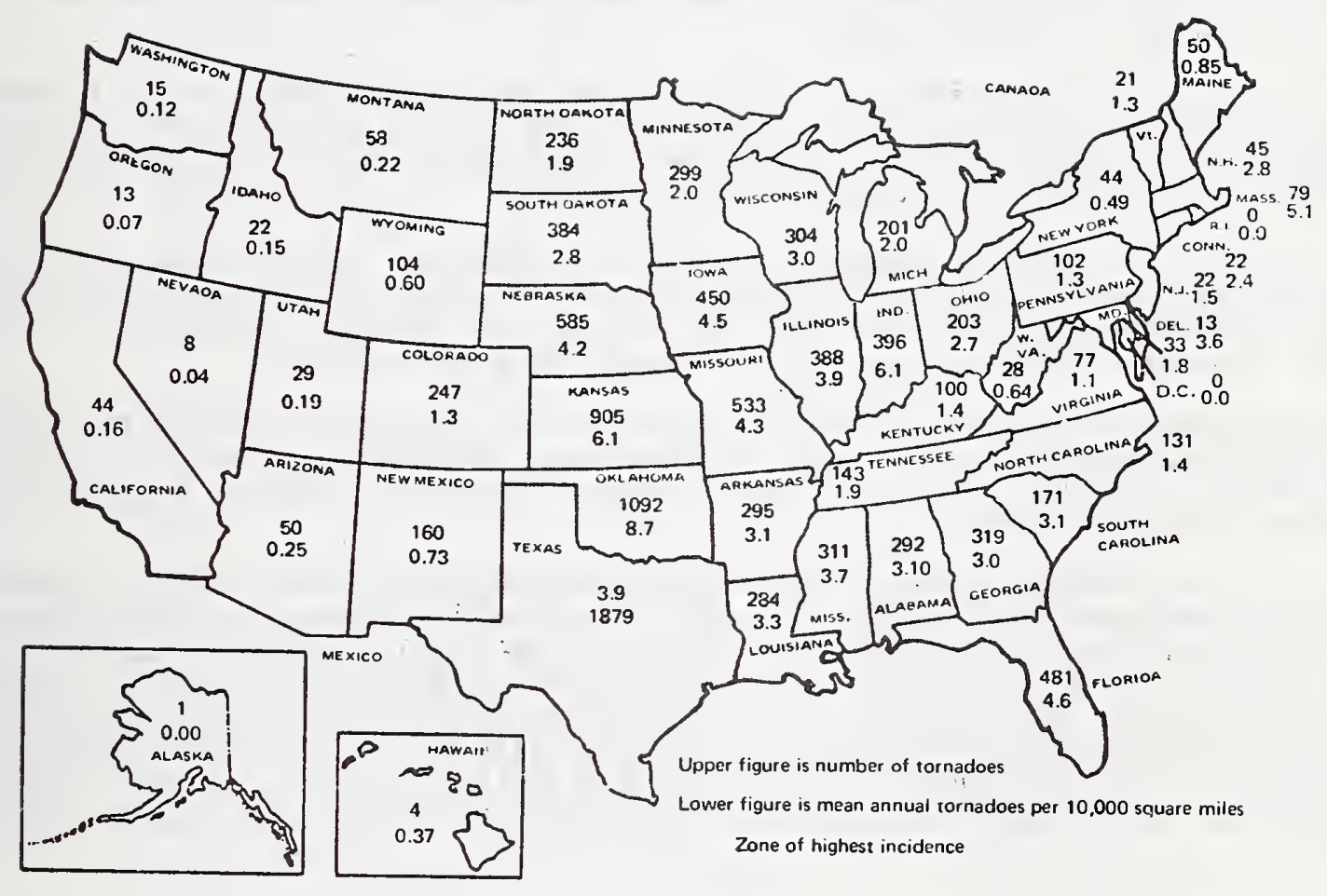

Figure 2.7 Tornado Incidence by State, 1953-1970

Source: U.S. Department of Commerce, National Oceanic and Atmospheric Administration, National Weather Service, Tornado Preparedness Planning (Washington, D.C.: Government Printing office, October 1970), p. 26. 
1953-1970. ${ }^{1}$ Although Texas has experienced the greatest number of tornadoes $(1,879)$, Oklahoma reportedly has a greater number of tornadoes (8.7) per 10,000 square miles than does any other state. In general the southeastern and midwestern states experienced the highest annual average number of tornadoes for the period.

In addition to being widespread, tornadoes occur frequently throughout the year, as shown in Figure 2。8. The peak tornado months are Apri1, May, and June. For the period 1953-1969, 2,465 tornadoes struck in the peak month of May. The number of tornado deaths has been correspondingly high during these months. For April, May, and June the total number of deaths during the same period was 578, 547, and 367, respectively. Figure 2.9 indicates that the states with the highest fatalities (per 10,000 square miles) are Indiana (40), Michigan (37), and Alabama (35).

The annual impact of tornadoes as reported by the American Red Cross is shown in Table 2.19. Since fiscal year 1965 an average of more than 8,300 families per year have suffered losses from tornadoes. Over the 14 year period described in Table 2.19, tornadoes destroyed and damaged an average of 6,871 dwellings per year.

Casualities and losses for individual tornadoes are reported in Table 2.20. The most devastating tornado disaster for the period was from a group of storms called the Palm Sunday Tornadoes, which resulted in 202 deaths and 1,813 destroyed dwellings (more than twice the number destroyed by any other tornado during the period).

The pecuniary losses to properties as a result of some individual tornadoes are listed in Table 2.21. On four occasions since 1965, tornadoes caused property damages of $\$ 100$ million and more. The damages produced by the Palm Sunday Tornadoes, previously mentioned, amounted to $\$ 200 \mathrm{million}$.

Annual dollar losses resulting from tornadoes have not been reported in such a manner so as to give researchers all the data they need for evaluating tornadoes. Broad categories of dollar losses, such as those shown in Table 2.18, are usually the best statistics available. For example, in 1965 and $1970 \mathrm{Table} 2.18$ shows losses of $\$ 50$ million and over (category 8). Yet if we compare these figures with the property damages shown in Table 2.21, we find that in 1965 the Palm Sunday Tornadoes produced $\$ 200$ million in property damages and that in 1970 the' tornadoes in Lubbock, Texas, caused $\$ 135$ million in property damages. The $\$ 50$ million and over category now appears very inappropriate for reporting tornado losses.

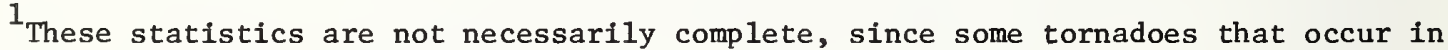
unpopulated areas are not recorded. 


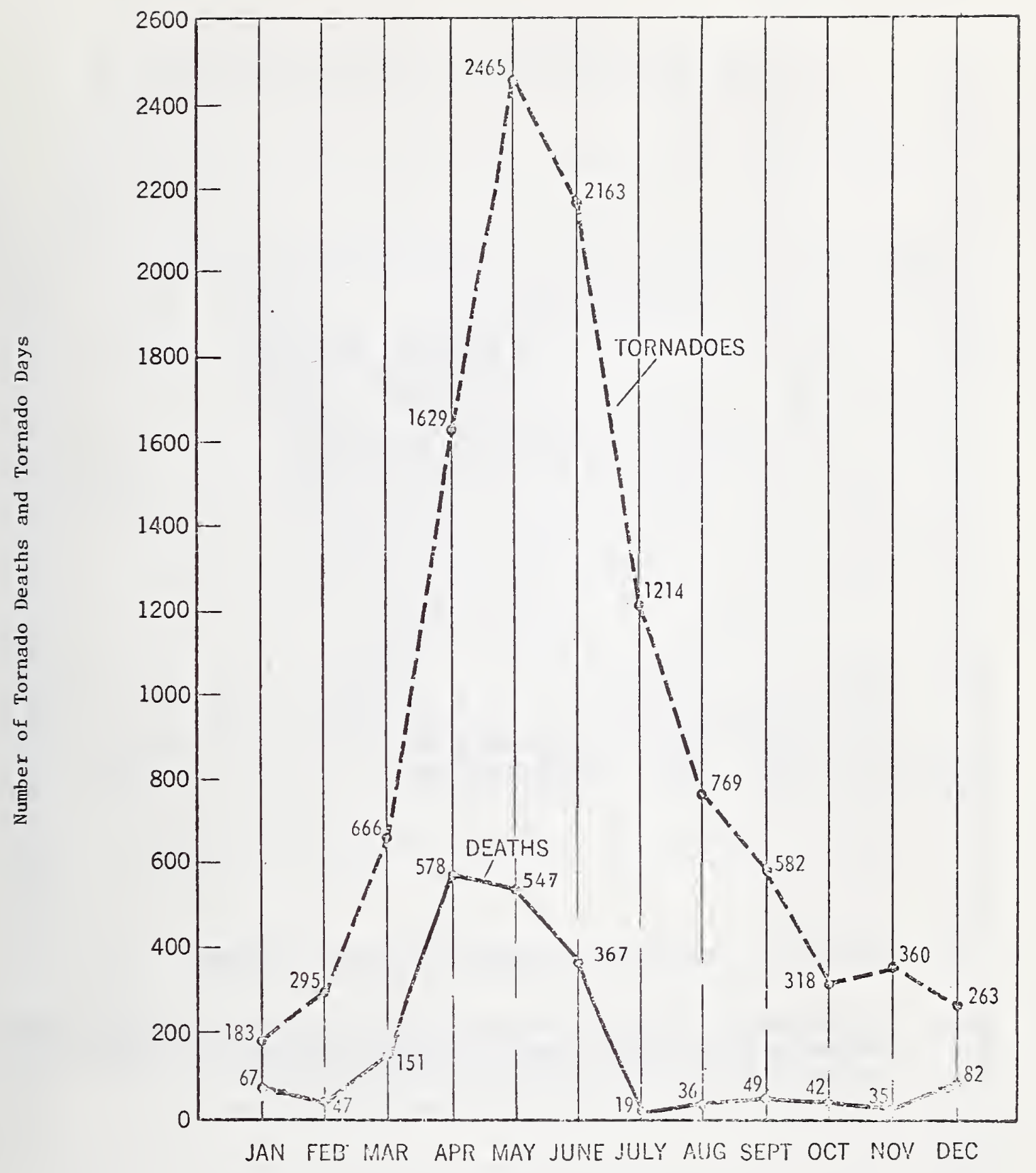

Figure 2.8 Distribution of Tornado Incidence and Resulting Deaths By Months, 1953-1969

Source: U.S. Department of Commerce, National Oceanic and Atmospheric Administration, National Weather Service, Tornado Preparedness Planning (Washington, D.C.: Government Printing Office, October 1970), p. 28. 


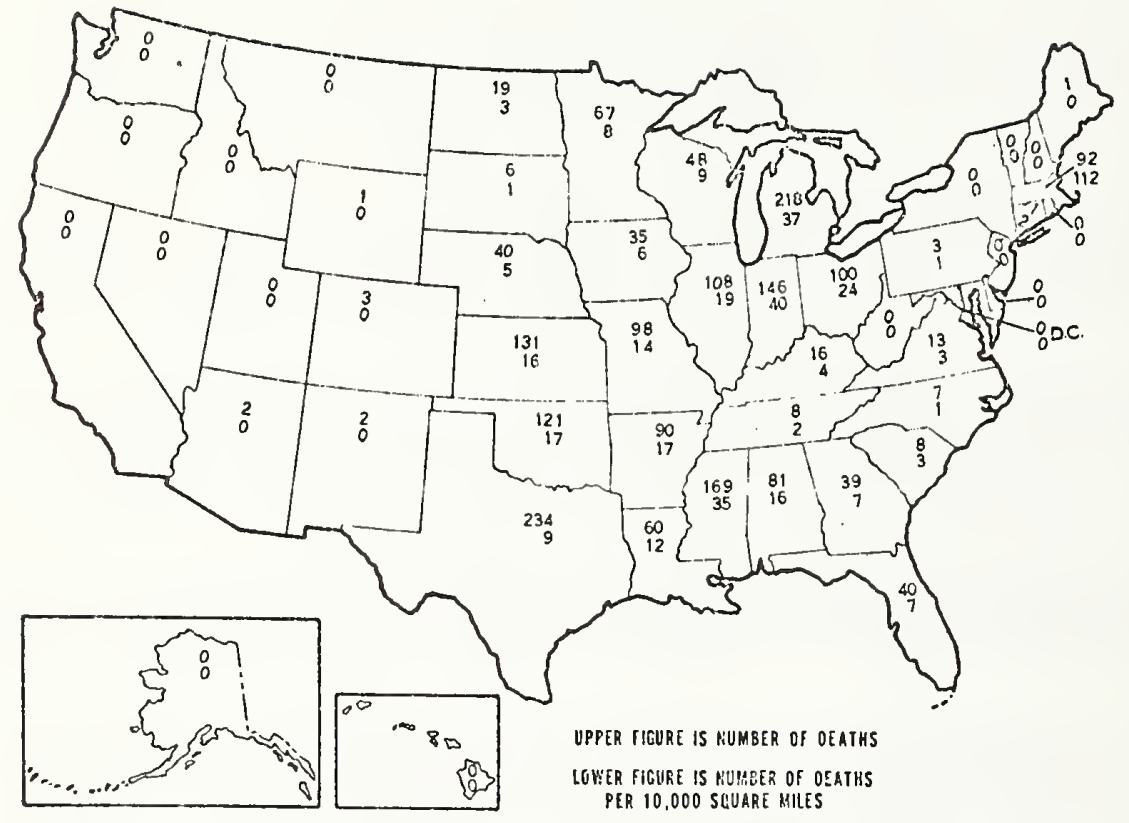

Figure 2.9 Deaths Due to Tornadoes, By State, 1953-1969

Source: U.S. Department of Commerce, National Oceanic and Atmospheric Administration, National Weather Service, Tornado Preparedness Planning (Washington, D.C.: Government Printing office, October 1970), p. 26. 


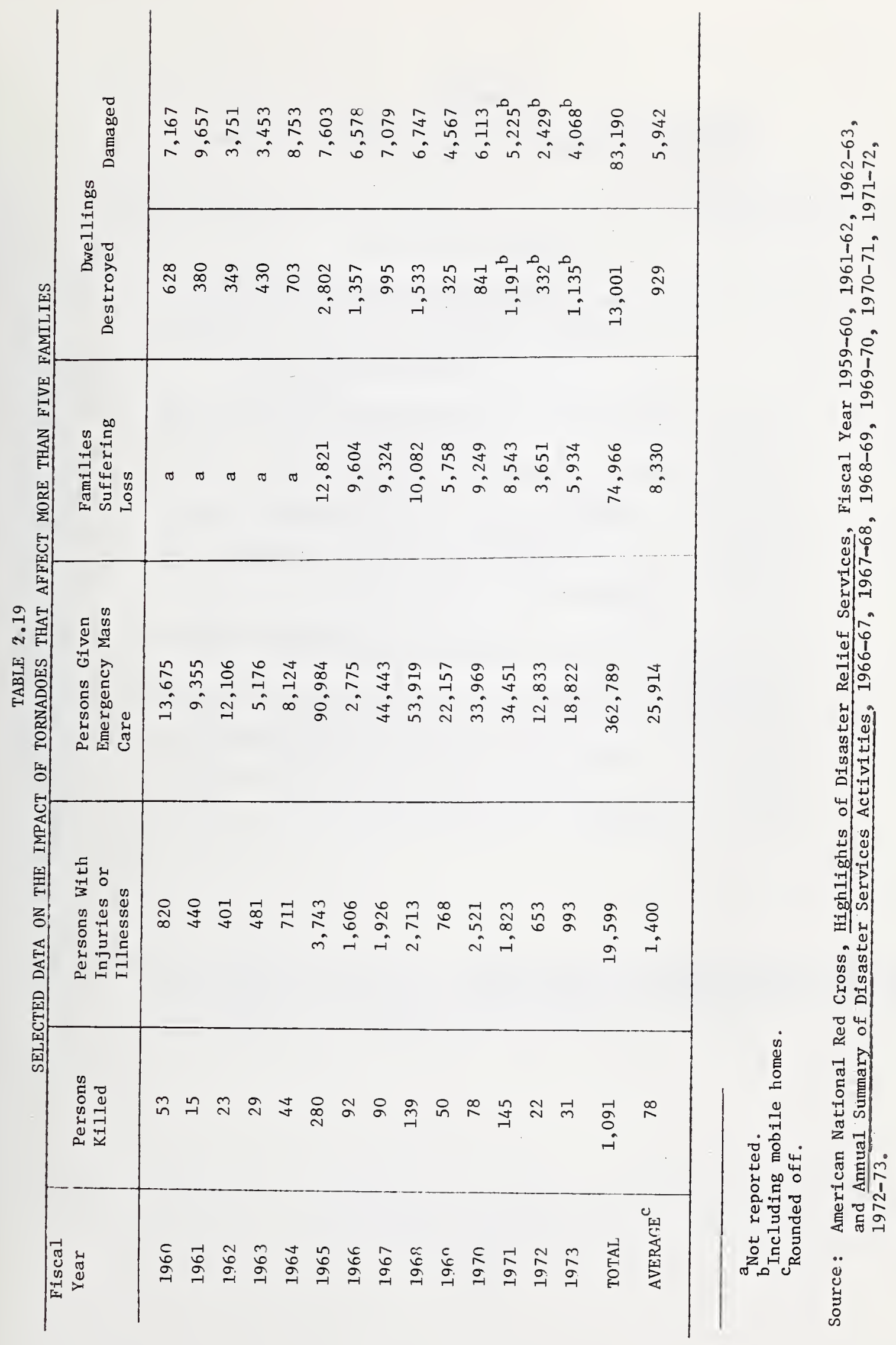


CASUALTIES AND LOSSES FROM SEVERE TORNADOES, 1955-1971

\begin{tabular}{|c|c|c|c|c|c|c|c|}
\hline \multirow[b]{2}{*}{ NAME OF DISASTER OPERATION } & \multirow{2}{*}{$\begin{array}{c}\text { DATE } \\
\text { OCCURRED }\end{array}$} & \multicolumn{3}{|c|}{ PERSONS } & \multicolumn{2}{|c|}{ DWELLINGS } & \multirow{2}{*}{$\begin{array}{l}\text { TOTAL NO. } \\
\text { FAMILIIES } \\
\text { SUFFE:RING } \\
\text { LOSS }\end{array}$} \\
\hline & & 号 & 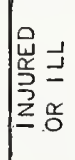 & 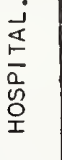 & 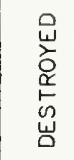 & 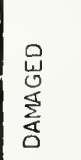 & \\
\hline OKLA.KANSAS TORNADOES & $5 / 25 / 55$ & 101 & 572 & 225 & 433 & 584 & 1199 \\
\hline $\begin{array}{r}\text { OKLA., KANSAS, MO. TORNAD- } \\
\text { OES }\end{array}$ & $4 / 25 / 56$ & 7 & 208 & 62 & 147 & 477 & 694 \\
\hline $\begin{array}{cc}\text { MISSOURI - KANSAS TORNAD- } \\
\text { OES } \\
\end{array}$ & $5 / 20 / 57$ & 54 & .448 & 163 & 625 & 1256 & 2261 \\
\hline $\begin{aligned} \text { MISSISSIPPI } & - \text { ALABAMA } \\
& \text { TORNADOES }\end{aligned}$ & $2 / 26 / 58$ & 15 & 123 & 62 & 143 & 276 & 494 \\
\hline $\begin{array}{r}\text { WEST CENTRAL WISCONSIN } \\
\text { TORNADOES }\end{array}$ & $6 / 4 / 58$ & 27 & 239 & 117 & 177 & 317 & 557 \\
\hline $\begin{array}{l}\text { PaIm Sunday Tornadoes } \\
\text { - INDIANA, OHIO - MAJOR } \\
\text { - KENTUCKY, W.VA. - MINOR }\end{array}$ & $4 / 11 / 65$ & 202 & 2047 & 636 & 181.3 & 2876 & 5492 \\
\hline EASTERN KANSAS TORNADOES & $6 / 8 / 66$ & 17 & 457 & 103 & 885 & 3317 & 5096 \\
\hline LUBBOCK, TEXAS TORNADO & $5 / 11 / 70$ & 26 & 1672 & 107. & 549 & 2033 & 3300 \\
\hline $\begin{array}{r}\text { WEST CENTRAL MISSISSIPP! } \\
\text { TORNADOES }\end{array}$ & $2 / 21 / 71$ & 117 & 1083 & 434 & 658 & 1014 & 2487 \\
\hline
\end{tabular}

Source: Data from American Red Cross. 
TABLE 2.21

PROPERTY DAMAGES RESULTING FROM INDIVIDUAL TORNADOES

Year Disaster Property Damages

$(\$ 1,000,000)$

1965

Palm Sunday Tornadoes

200

1966

Topeka, Kansas

100

1967

St. Louis County, Missouri

15

1968

Charles City, Iowa

30

1969

Salina, Kansas

10

1970

Lubbock, Texas

135

1971

Mississippi Delta Tornadoes

20

1972

Vancouver, Washington

5-6

1973

North Central, Georgia

113

Source: U.S. Department of Commerce, National Oceanic and Atmospheric Administration, Environmental Data Service, General Summary of Tornadoes 1965, 1966, 1967, 1968, 1969, 1970, 1971, 1972 (Washington, D.C.: Government Printing Office); and Storm Data and Unusua1 Weather Phenomena, March 1973. 


\section{BENEFIT-COST ANALYSIS}

The previous chapter discussed the past dollar losses and other consequences of natural disasters. The reasons for studying these past losses is to determine the potential benefits that might be realized from protection against future disasters. Society can purchase protection through various techniques that are effective in reducing future losses. The problem facing society is one of deciding how much disaster protection it is economical to buy. The present chapter will apply a well-known method, called benefit-cost analysis, for choosing society's optimal level of protection against natural disasters.

Benefit-cost analysis can also be applied to determining the proper channeling of research money into disaster mitigation programs. This is accomplished by examining the potential benefits and costs of alternative research strategies. It is desirable to determine if the potential benefits from various research programs will justify their costs. When several research possibilities exist, a benefit-cost analysis provides a rational approach for choosing among research projects.

The first section of this chapter discusses the principles of benefit-cost analysis and their application to evaluating alternative levels of protection against natural disasters. The second section will examine the results of two studies in disaster mitigation.

\subsection{Benefit-Cost Models for Disaster Mitigation}

Alternative levels of protection against natural disasters provide certain benefits and costs for society. Social benefits are the reduction of future potential losses resulting from natural disasters. The costs (opportunity costs) society must incur to achieve these benefits are the benefits foregone by taking resources out of their alternative uses and applying them to disaster protection. To use resources efficiently, society must choose the optimal level of protection that maximizes the difference between the present value of total benefits and total costs. A benefit-cost model can be used to determine society's optimal level of protection against natural disasters.

The essential features of a benefit-cost model can be illustrated by graphical analysis. In Figure 3.1 the horizontal axis measures alternative levels of protection, $P$. The vertical axis measures the dollar value of total benefits and total costs for corresponding levels of protection. The total benefits curve is shown increasing at a decreasing rate. This is a tenable proposition as long as equal increments of protection result in successively smaller reductions in losses.

The total costs of protection in Figure 3.1 are depicted as increasing at an increasing rate. This reflects diseconomies of scale that result when equal increments in productive resources yield diminishing increments in disaster protection.

The decision rule for optimization in benefit-cost analysis is to choose that program or level of protection which maximizes the difference between total benefits and total costs;

$1_{B e c}$

${ }^{1}$ Because of a positive rate of time preference, the potential benefits and costs do not have the same value in the future as they do today. Based on society's valuation of future relative prices, a future stream of benefits and costs can be discounted to their present value. Throughout the following benefit-cost analysis all dollar values of benefits and costs will be taken to be present values. 
Dollar Value of Total Benefits and Total Costs

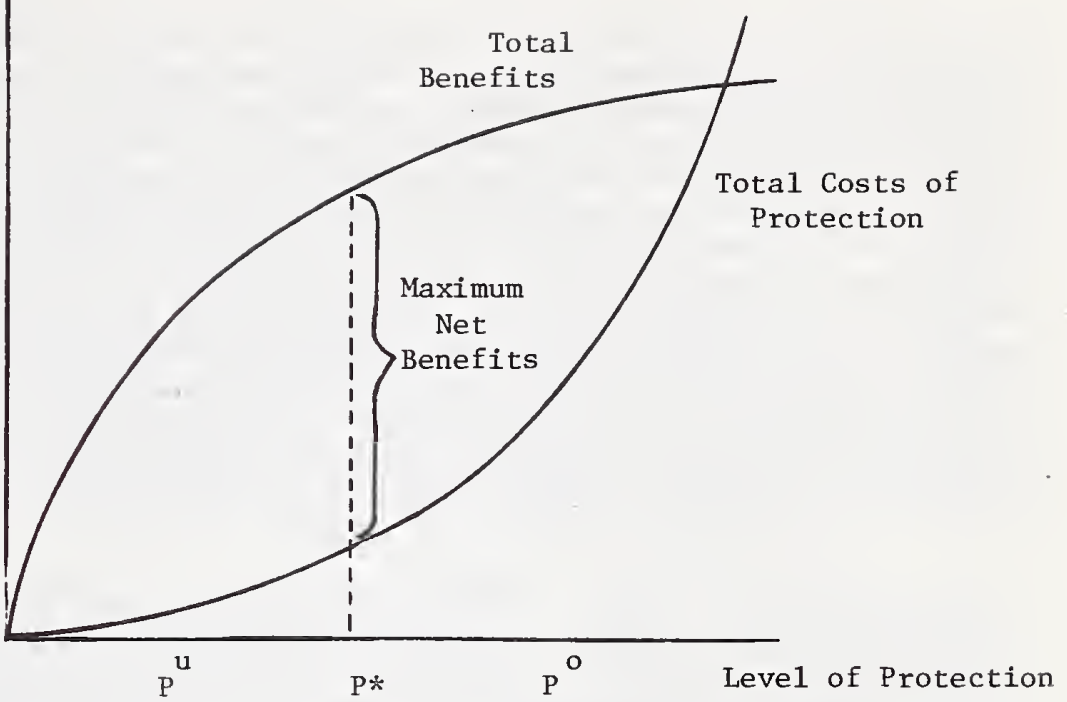

Figure 3.1 Dollar Value of Total Benefits and Total Costs versus level of protection against natural disasters
Do1lar Value of Margina1

Benefits and Margina1 Costs

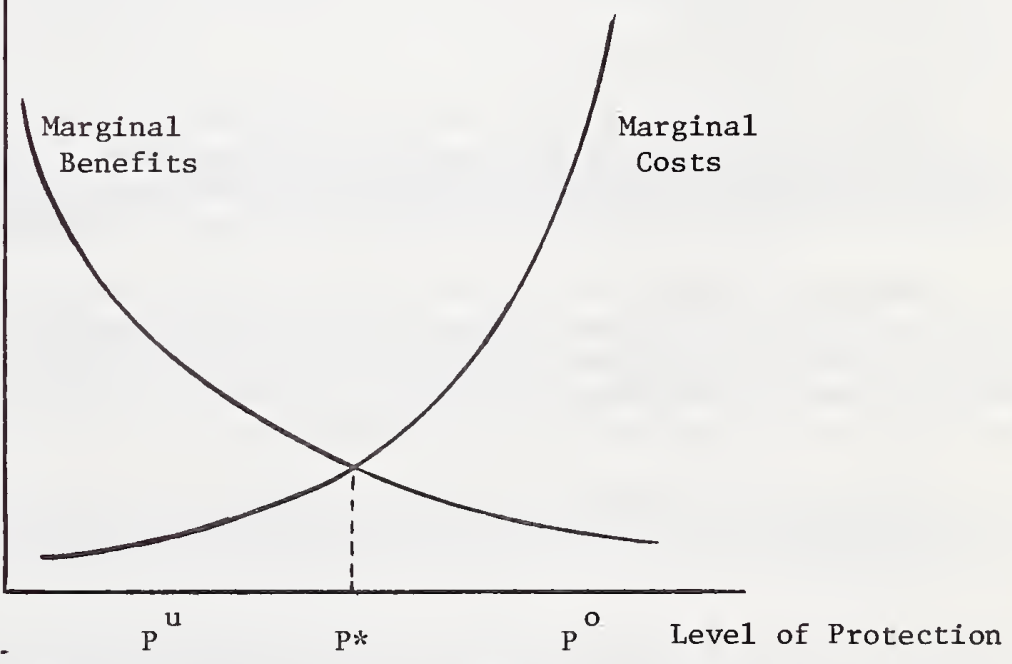

Figure 3.2 Do1lar Value of Marginal Benefits and Marginal Costs versus Level of Protection Against Natural Disasters 
i.e., maximizes net benefits. ${ }^{1}$ This criterion can be restated as choosing that level of protection which equates marginal benefits to marginal costs. Figure 3.1 shows that society's optimal level of disaster protection occurs at $\mathrm{P}$, where net benefits are maximized. Correspondingly, Figure 3.2 shows that marginal benefits just equal marginal costs of protection at $\mathrm{P} *{ }^{2}$ Any level of protection greater than $\mathrm{P}$, for example $\mathrm{P}^{\circ}$ in Figures 3.1 and 3.2 , indicates that society is over-protecting against disasters. $P^{\circ}$ represents an inefficient allocation of society's scarce resources. By instituting lower levels of protection (moving toward $\mathrm{P}^{*}$ ) soclety's reduction in costs is more than the reduction in benefits. Net benefits will be increased (Figure 3.1) and an equality between marginal benefits and marginal costs will be approached (Figure 3.2). Similarly, any level of protection less than $\mathrm{P}^{*}$, say $\mathrm{P}^{\mathrm{u}}$ in Figures 3.1 and 3.2 , is a signal that soclety is underprotecting against natural disasters. By increasing the level of protection from $P^{u}$ to $P *$, net benefits increase, marginal benefits abroach marminal costs, and a more efficient allocation of resources results. Once $P^{*}$ is achieved no other level of protection will, produce a more efficient choice for society.

An equally useful ${ }^{3}$ method of determining soclety's optimal level of protection against natural disasters involves total cost minimization, where total costs are defined to include more than fust the costs of protection. Figure 3.3 will be used to illustrate this method. The horizontal axis measures alternative levels of protection ( $P$ ) and the vertical axis measures the corresponding dollar values (discounted to the present) of costs of protection, total losses, and total costs (costs of protection plus total losses). The costs of protection curve of Figure 3.3 is idęntical to the total costs of protection curve appearing in Figure 3.1. A total losses curve is shown decreasing at a decreasing rate for increasing levels of protection: i.e., equal increments of protection add successively smaller reductions in losses. Decreasing total losses are vertically added to increasing costs of protection in order to derive a third curve, labeled total costs. Under the cost minimization principle, the optimal level of disaster protection is achieved when total costs (costs of protection plus total losses) are minimized. This is shown to occur at P** in Figure 3.3. The cost minimization method produces a result precisely the same as the benefit-cost method for selecting the optimal level of protection: i.e., $\mathrm{P} *$ (Figure 3.3 ) is equal to $\mathrm{P} * 5$

(Figures 3.1 and 3.2 )

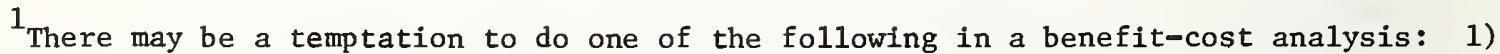
maximize total benefits or 2) require only that total benefits exceed total costs. The first will cause an inefficient allocation of resources and a non-optimal level of protection. The second will also more than likely cause a non-optimal choice.

2

2 Marginal benefits and marginal costs are the additions to total benefits and total costs resulting from a small change in the level of protection. To derive the marginal benefits curve and marginal costs curve we calculate the rate of change in total benefits and total costs at alternative levels of protection. Mathematically, the marginal curves are the first derivatives of the total curves.

${ }^{3}$ Although not referred to as cost minimization, this method can be found in Clifford S. Russel1's article "Losses from Natural Disasters," Land Economics, Vol. 46 (November 1970), pp. 383-393.

${ }^{4}$ Note that the total benefits curve previously discussed is derived using the total losses curve. The total benefits curve is merely the total losses curve subtracted from the level of losses incurred in the absence of any protection. See appendix.

${ }^{5}$ See appendix for a mathematical proof of this statement. 


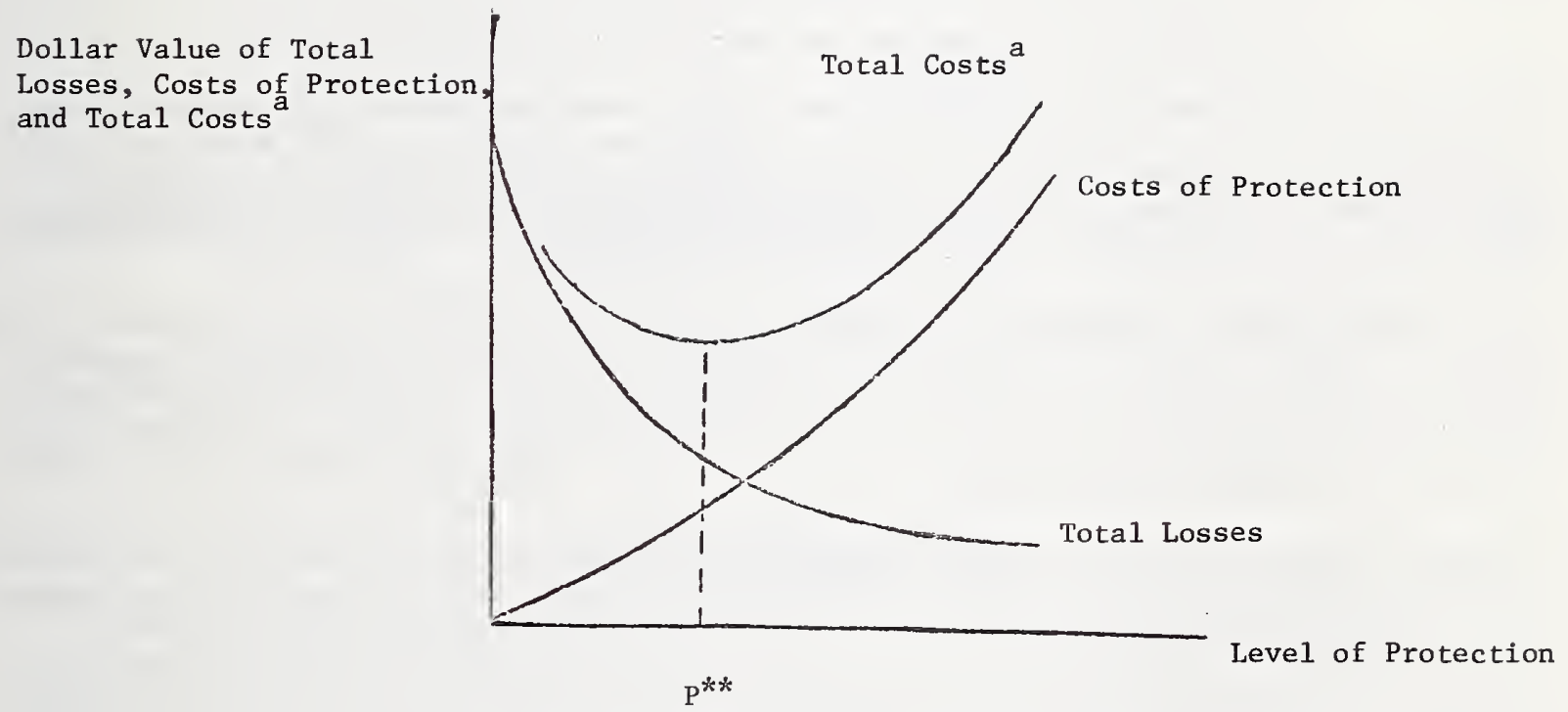

Figure 3.3 Dollar Value of Total Losses, Costs of Protection,

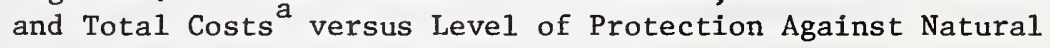
Disasters

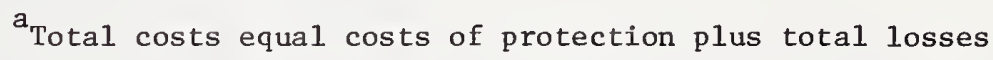


By protecting at a level greater than $\mathrm{P}^{* *}$, costs of protection increase by more than total losses decrease. Total costs (costs of protection plus total losses) increase (a movement upward and to the right occurs along the total costs curve) and are no longer at a minimum. When the level of protection against natural disasters is reduced below P**, total losses increase by an amount greater than the decrease in costs of protection. Again, total costs increase and deviate from the possible minimum. Any level of protection different from $P * *$ results in a movement away from minimum total cost and hence a non-optimal level of protection against natural disasters.

In this section we have examined two approaches for determining the optimal level of protection. The level of protection considered in both may be produced by a combination of available techniques or by only one technique of protection. Thus it is emphasized that, when several approaches do in fact exist, they must all be included in the optimization problem; otherwise, an optimal solution may not be achieved.

\subsection{Application of Benefit-Cost Analysis to Disaster Mitigation}

In this section the essential features of two studies concerned with mitigating the losses from disasters will be discussed. The studies apply two techniques to two different types of problems. The studies reviewed are 1) A Preliminary Study of Engineering Seismology Benefits, and 2) Application of Economic Analyses to Hurricane Warnings to Residentia1 and Retail Activities in the U.S. Gulf of Mexico Coastal Region.

A Preliminary Study of Engineering Seismology Benefits ${ }^{1}$ investigates the determination of the economic benefits derived from engineering seismology. The report estimates the economic benefits realized from the passage of the California Field Act. This act was passed by the California State Legislature following the Long Beach earthquake in 1933. It revised the building codes so that all California schools constructed after 1933 would be able to better withstand the effects of earthquakes.

The study compares earthquake damages among schools constructed before the 1933 code revision and schools constructed after (with) the revision. Estimated dollar damages were calculated for 59 schools and four earthquakes. The earthquakes included Imperial Valley (1940), Torrance-Sardina (1941), Kern County (1952), and Daly City (1957). Earthquake magnitudes as measured by the Richter scale were $7.1,5.4,7.7$, and 5.3 respectively. The dollar damage as a percent of building value at the time of the earthquake was computed for each school. The damage was determined by estimating the cost of restoring a school to its pre-earthquake condition.

Figure 3.4 plots damages as a percentage of building value for different earthquake intensities for schools built prior to 1933 (upper curve) and for schools built later than 1933 (lower curve). For each intensity rating, the curves show the average school damage as a percent of building value. California schools constructed under the earthquake-resistant regulations of the Field Act sustained considerably less damage, as a percent of building

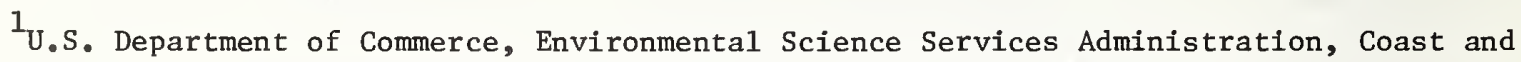
Geodetic Survey, A Preliminary Study of Engineering Seismology Benefits (Washington, D.C.: Government Printing Office; August 1967).

I Ibid., p. 15 . 
DAMAGE

$(\%$ OF VALUE)

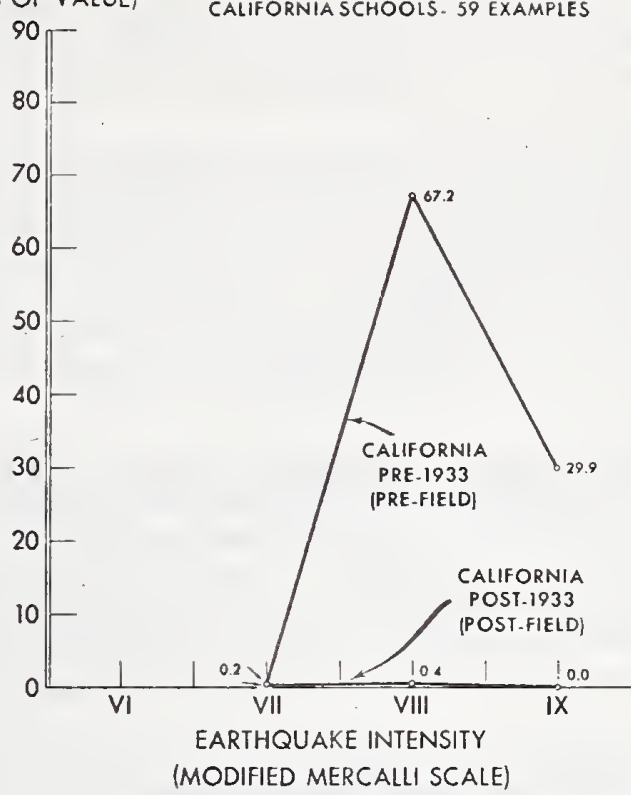

Figure 3.4 -Eorthquake domage-Californio schools.

DAMAGE

(\% OF VALUE) CALIFORNIA SCHOOLS. 59 EXAMPLES

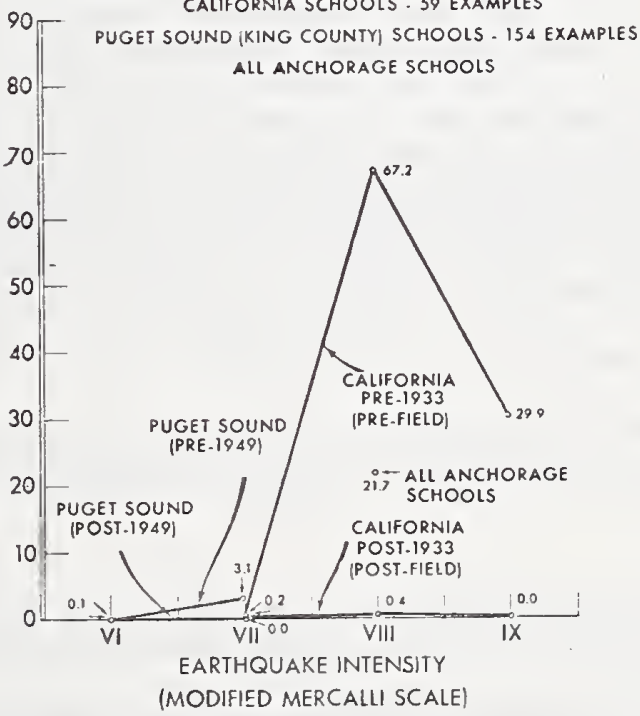

Figure 3.5 Earihquake damage-Colifornia schools, Puget Sound (King County) schools, and Ancharage schools. 
value, than schools constructed prior to the code revision. ${ }^{1}$ While the former schools experienced an average damage-to-value percentage of 0.4 at an Intensity of VIII, the latter schools experfenced a 67.2 damage-to-value percentage at the same intensity.

The benefits derlved from instituting an earthquake-reslstant building code are significant, as Figure 3.4 indicates. However, the costs of code revision have been neglected. Consequent1y, it has not been determined whether or not the benefits derived from providing earthquake protection through code revision exceed or fall short of the costs for such protection. This, in turn, leads to the question of whether or not society implemented the optimal level of protection against the effects of earthquakes, or whether society is overprotecting (too stringent a code) or underprotecting (in which case a more stringent code should be enforced).

A similar study was conducted for school buildings in Puget Sound, Washington. Damages to school buildings were compared on a pre-1949 and post-1949 construction basis. Since 1949 Seattle has been under the auspices of the Uniform Building Code and a provision for earthquake-resistant construction. As a result, school buildings constructed after 1949 have experienced smaller damages as a percent of their building value than have school buildings constructed before 1949 (see Figure 3.5). The benefits are well defined, but again the social and economic costs of code revision are disregarded in the analysis.

Another empirical study that provides an example of benefit-cost analysis is Application of Economic Analysis to Hurricane, Warnings to Residential and Retail Activities in the U.S. Gulf of Mexico Coastal Region. This study applies the principles of game theory to decisions involving improved hurricane prediction and warning systems--a technique of protection against hurricanes. An estimated savings of $\$ 15.2$ million (as a lower bound estimate) can be realized in the firşt year from reducing the error of present prediction and warning, according to the study.

People who receive hurricane warnings do not always act rationally. Some do not take protective action against potential effects the storm has on homes and businesses. Anderson and Burnham have calculated the potential savings from averting damages when increased proportions of the population take protective action (Table 3.1). Table 3.2 shows the estimated savings from averting damages when the population grows annually at $5 \%$ and an additiona1 $10 \%, 20 \%, 60 \%$ and $100 \%$ of the people who do nct take protective action now decide to take protection. Taking year 1 as an example, $20 \%$ of the current population present1y take protective action when alerted, $80 \%$ do not. Let us assume, however, that $10 \%$ of the $80 \%$ who do not protect now decide to take protective action. Thus, $20 \%+(10 \% \times 80 \%)$ or $28 \%$ now take protection. With population growing at an annual rate of $5 \%$, an estimated $\$ 3.18$ million in damages can be averted. By year 4 , when $100 \%$ of the new population takes protective action, savings can amount to $\$ 13.33$ million.

The report also develops a game theory approach to the decision of whether or not to protect. The general model is presented in Figure 3.6. Given the probability (p) of a hurricane

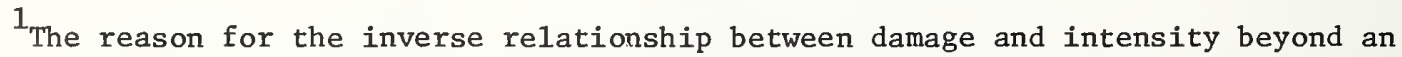
intensity of VIII is explained in the report as being caused by variation in sample size.

${ }^{2}$ Lee G. Anderson and John M. Burnham, "Application of Economic Analysis to Hurricane Warnings to Residential and Retail Activities in the U.S. Gulf of Mexico Coastal Region," Monthly Weather Review, February 1973, pp. 126-131.

3 Ibid., p. 126 . 


\section{TABLE 3.1}

DAMAGE REDUCTION DUE TO INCREASING PERCENT OF POPULATION PROTECTING AGAINST HURRICANES

Proportion of Alterted Population

That Takes Protective Action

$(\%)$
Damage Averted

$$
(\$ 1 ; 000,000)
$$

$\begin{array}{lr}20 & 2.16 \\ 40 & 4.32 \\ 60 & 6.48 \\ 80 & 8.64 \\ 100 & 10.80\end{array}$

Source: Lee G. Anderson and John M. Burnham, "Application of Economic Analysis to Hurricane Warnings to Residential and Retail Activities In the U.S. Gulf of Mexico Coastal Region," Monthly Weather Review. February 1973, p. 127. 
DAMAGE REDUCTION WITH POPULATION GROWTH AND INCREASED PROTECTION BY POPULATION

\begin{tabular}{lccccc}
\hline & \multicolumn{1}{c}{$(1)$} & \multicolumn{1}{c}{$(3)^{\mathrm{a}}$} & \multicolumn{1}{c}{$(4)$} & $(5)^{\mathrm{b}}$ \\
& $\begin{array}{l}\text { Percent of } \\
\text { Population } \\
\text { Now Protecting }\end{array}$ & $\begin{array}{l}\text { Increased } \\
\text { Percent of } \\
\text { Population } \\
\text { Protecting }\end{array}$ & $\begin{array}{l}\text { Percent of } \\
\text { New Population } \\
\text { Protecting }\end{array}$ & $\begin{array}{l}\text { Population } \\
\text { Growth } \\
\text { Rate } \\
(\%)\end{array}$ & $\begin{array}{l}\text { Damage } \\
\text { Averted } \\
(\$ 1,000,000)\end{array}$ \\
\hline Year 1 & 20 & 10 & 28 & 5 & 3.18 \\
Year 2 & 20 & 20 & 36 & 5 & 4.29 \\
Year 3 & 20 & 60 & 68 & 5 & 8.50 \\
\hline
\end{tabular}

${ }^{\mathrm{a}} \operatorname{Col} \cdot 1+\operatorname{Co1} \cdot 2^{\cdot}(100 \%-\operatorname{Col} \cdot 1)$.

${ }^{b}$ Co1. $3 \cdot(1.05)^{t} \cdot \$ 10.8$ million, where $t=1,2,3,4$.

Source: Lee G. Anderson and John M. Burnham, "Application of Economic Analyses to Hurricane Warnings In the U.S. Gulf of Mexico Coastal Region," Monthly Weather Review, February 1973, p. 127. 


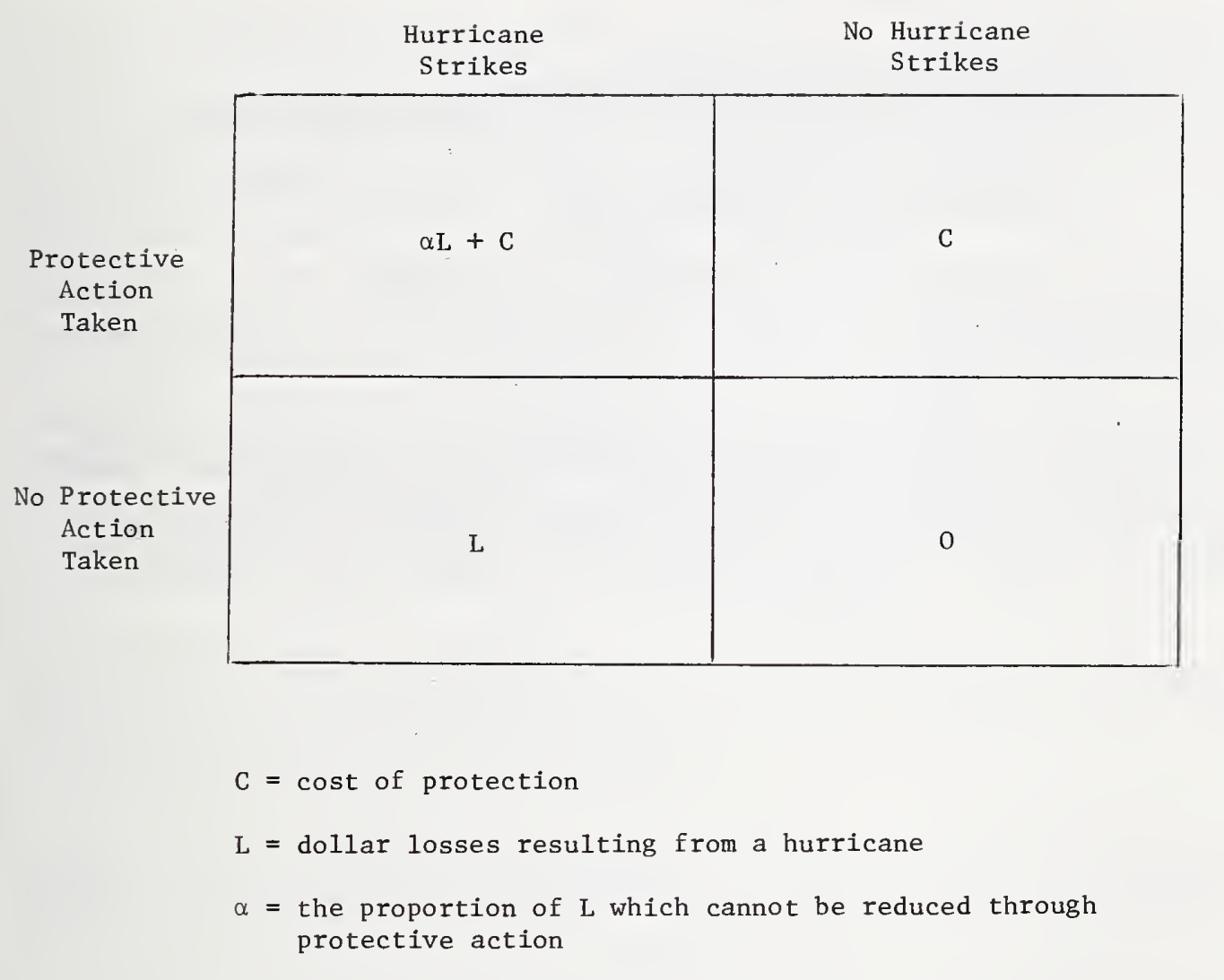

Figure 3.6 Hurricane decision matrix

Source: Lee G. Anderson and John M. Burnham, "Application of Economic Analysis to Hurricane Warnings to Residential and Retail Activities In the U.S. Gulf of Mexico Coastal Region," Monthly Weather Review. February 1973, p. 127. 
passing over a given area at a given time, then the hurricane forecast should be given only if

$$
\mathrm{p}(\alpha \mathrm{L}+\mathrm{C})+(1-\mathrm{p}) \mathrm{C}<\mathrm{pL},
$$

where $\mathrm{C}=$ cost of protection,

$\mathrm{L}=$ dol.lar losses resulting from a hurricane, and

$\alpha=$ the proportion of $\mathrm{L}$ which cannot be reduced through protective action.

The left hand side of the inequality represents the expected cost of protecting. The right hand side represents the expected cost of not protecting.

Anderson and Burnham also show that the above expression can be reduced to $\mathrm{p}>\frac{\mathrm{C}}{(1-\alpha) \mathrm{L}}$. So a forecast warning should not be given unless the probability of the storm striking an area ( $p$ ) is greater than $\frac{C}{(1-\alpha) L}$

The approach can be adapted to the analysis of individual decisions regarding protection against any type of natural disaster. Given the probability of a natural disaster striking, an individual can assess the values of $\mathrm{C}, \mathrm{L}$, and $\alpha$ and thus determine whether or not it pays to protect against the potential losses of the disaster. Based on an individual's relative valuation of $\mathrm{C}, \mathrm{L}$, and $\alpha$, it becomes feasible for the individual to protect against the disaster only when $\mathrm{p}>$

$\frac{C}{(1-\alpha) L}$ 


\section{SUMMARY AND RECOMMENDATIONS}

\subsection{Summary}

An understanding of the relative losses resulting from various types of disasters and individual occurences of disasters is useful to both the individual and society. The individual will be better prepared to assess the potential losses of various disasters and how and to what extent he should protect himself from such 1osses. Society, in its efforts to mitigate the losses from disasters, will have better information on the basis of which to determine the levels of protection against disasters which maximize net benefits. The following section summarizes and compares the monetary and non-monetary losses associated with the four types of disasters discussed in Chapter $2 .{ }^{1}$

The dollar values of property damages resulting from hurricanes and floods for five-year periods between 1950 and 1969 are shown in Figure 4.1. Comparative damages for tornadoes and earthquakes are shown for five-year periods between 1950 and 1964. Between floods and hurricanes, floods caused the greatest amount of total damages ( $\$ 7046$ million from floods compared to $\$ 6008$ million from hurricanes)。Also, during the period 1950-1954 flooding caused more tota1 property damage than hurricanes, earthquakes, or tornadoes.

Figure 4.2 shows the comparative number of lives lost for the four types of disasters during the period 1950 to 1969. Tornadoes caused the greatest total loss of lives $(2,348)$ and also caused the most deaths in any five-year period.

The decreasing trend in the number of lives lost from disasters in general is not evident in Figure 4.2. The short time period covered or the large five-year intervals may distort the trend other researchers have uncovered. Figure 2.1, Chapter 2 of this report, shows a strong downward trend of lives lost due to hurricanes. This trend, however, is not as apparent for other types of natural disasters.

Assuming that the quality of the statistics reported has not changed significantly between 1969 and 1972, we can compare the relative losses resulting from severe individual disasters. Figures 4.3 and 4.4 show the comparative losses resulting from Hurricane Camille (1969), the Agnes Floods (1973), the San Fernando Earthquake (1971), and the Lubbock, Texas Tornado (1970).

The disaster with the greatest property damages among the four occurences shown in Figure 4.3 was the Agnes Floods ( $\$ 2,100$ million). The number of lives lost during these floods numbered 122. Hurricane Camille took $47 \%$ more lives (258) than did the Agnes floods, but caused $32 \%$ less property damage ( $\$ 1,420.7$ million).

Figure 4.4 shows the comparative number of dwellings destroyed and damaged by each of the four disasters. Hurricane Camille accounted for $48 \%$ of the total number of dwellings destroyed by the four disasters ( 6013 out of a total of 12,534). The Agnes Floods destroyed $42 \%$ or 5,222 of the total dwe1lings.

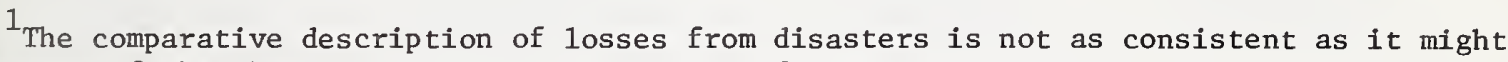
be because of the changing quantity and quality of statistics reported over the years.

${ }^{2}$ See Douglas C. Dacy and Howard Kunreuther, The Economics of Natural Disasters

(New York: The Free Press, 1969), p. 7.

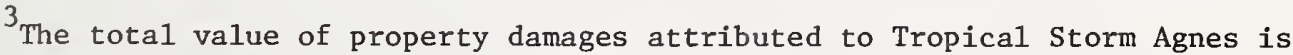
$\$ 3,097.8$ million (see Table 2.6, Chapter 2). 
Property Damages

$(\$ 1,000,000)$

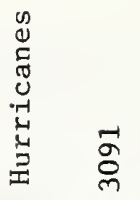

3,000

2,000

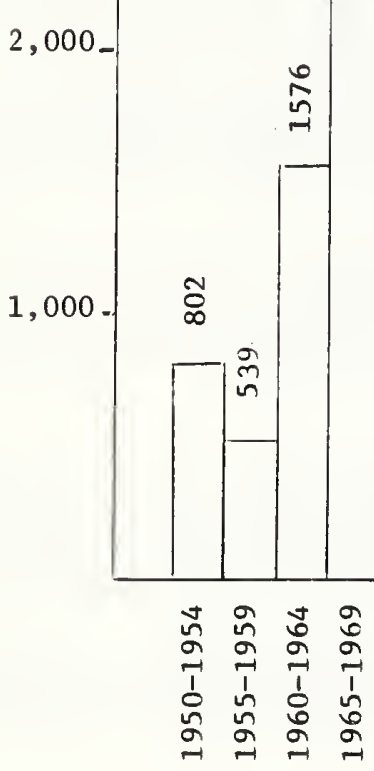

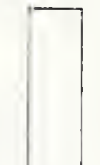

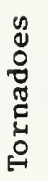

章

$\stackrel{\text { s }}{5}$

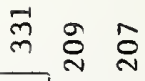

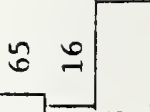

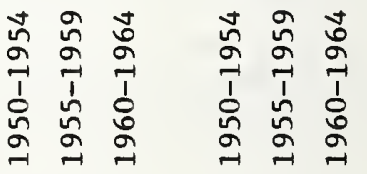

Figure 4.1 Property Damages Resulting from

Hurricanes, Floods, Tornadoes and Earthquakes 


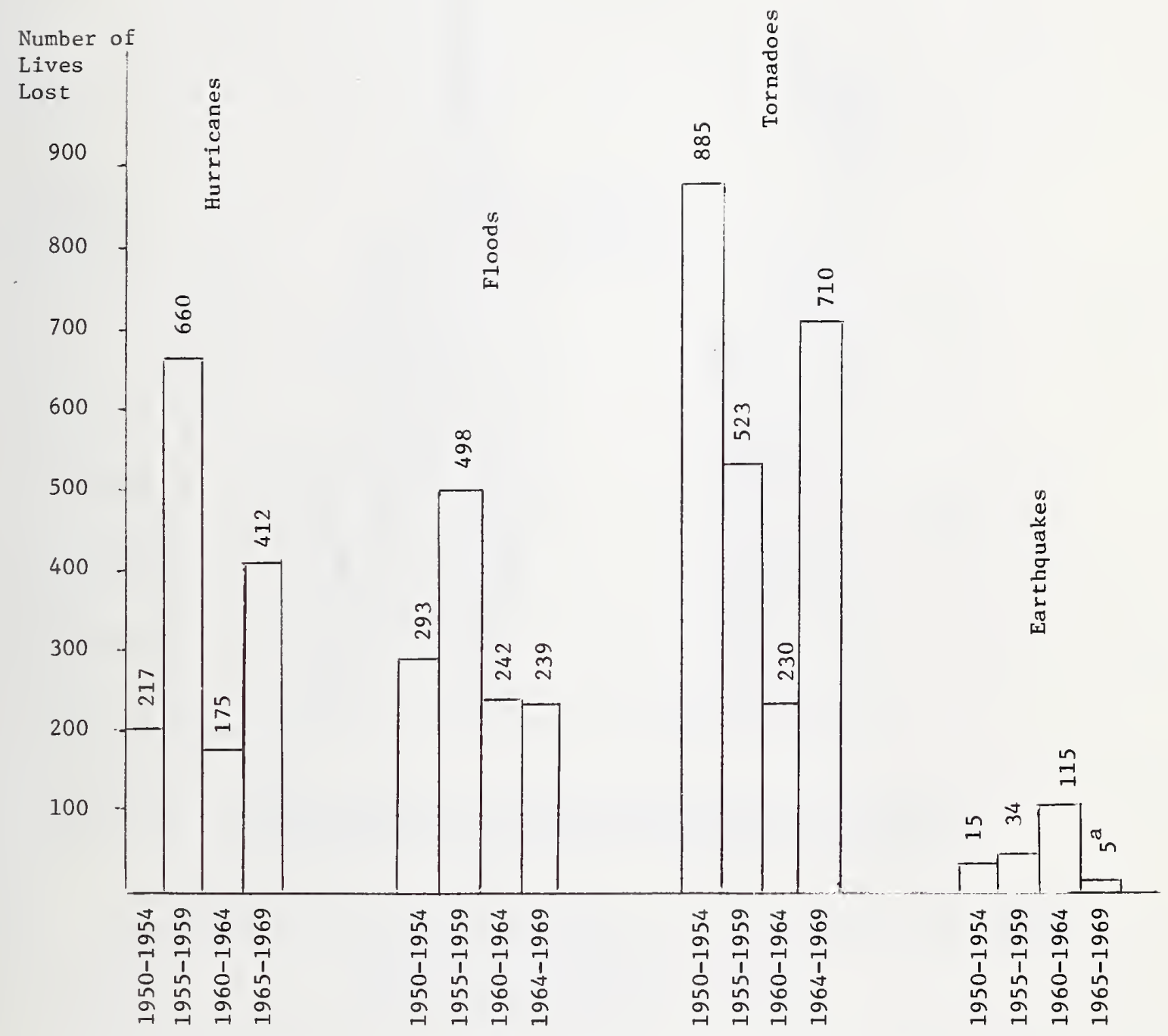

Figure 4.2 Number of lives lost due to hurricanes, floods, tornadoes, and earthquakes

${ }^{a}$ Puget Sound, Washington earthquake only. 
Property Damages

$(\$ 1,000,000)$

4, 000

4,000

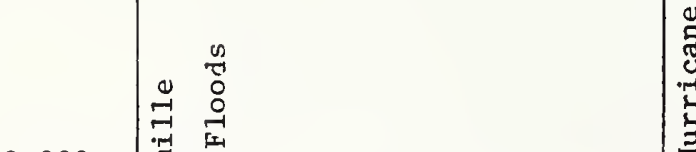

3,000

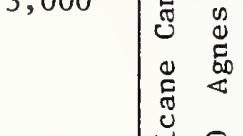

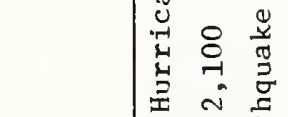

$2,000-\frac{5}{\pi}$

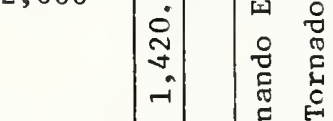

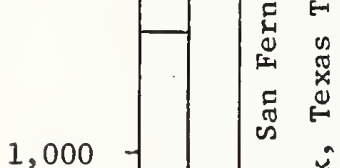

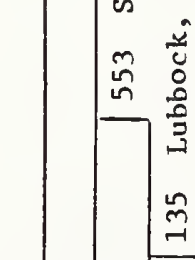

Lives Lost

省

$\stackrel{\infty}{\stackrel{n}{N}}$
240

220

200

180

160

140

120

100

80

60

20

$40 . \quad$ 는

Figure 4.3 Comparisons of property damages and number of lives lost for individual disasters, 1970-1972

${ }^{a}$ Deaths due to hurricane winds and flooding were not reported separately. 


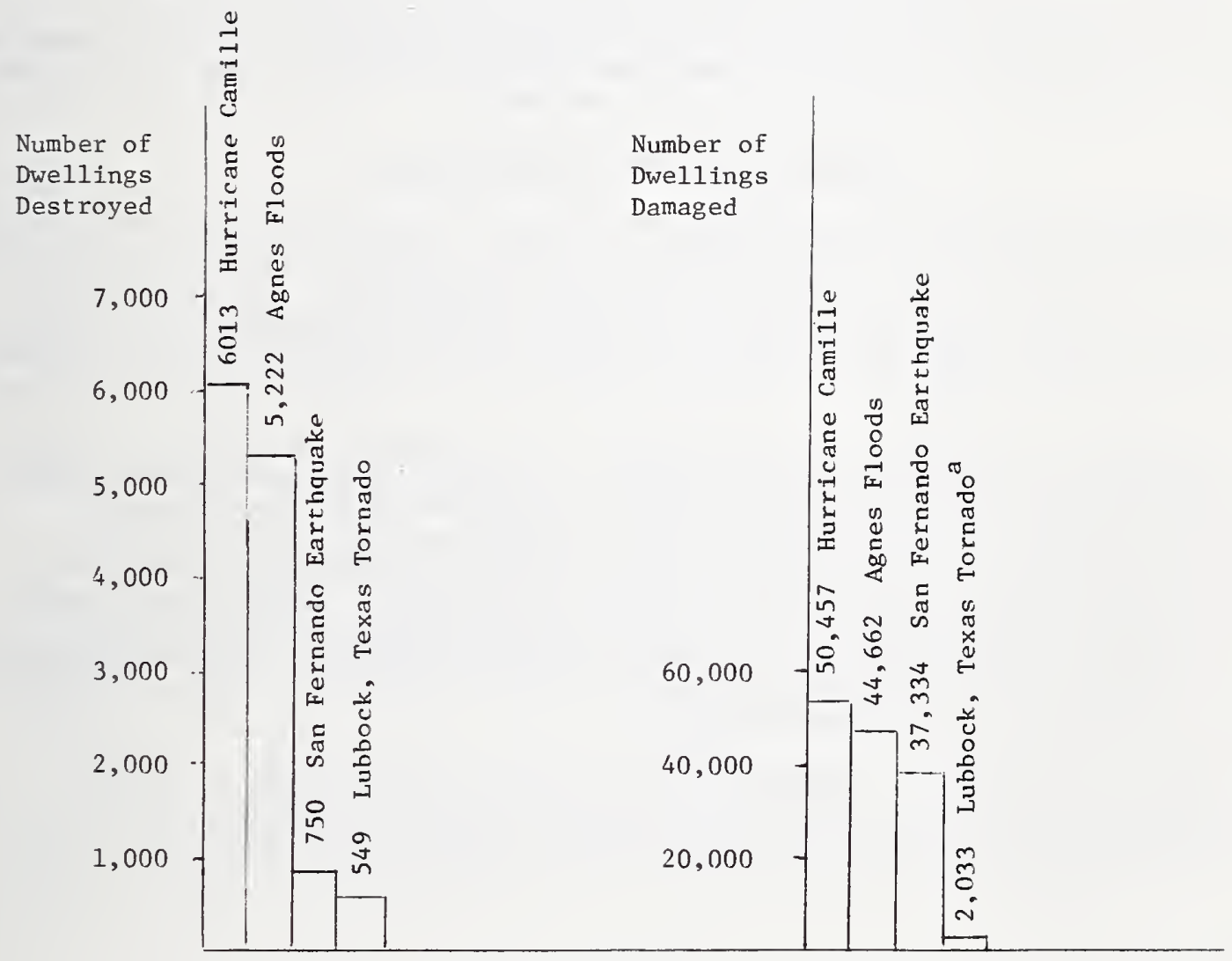

Figure 4.4 Comparisons of number of dwellings destroyed and damaged

for individual disasters, 1970-1972

${ }^{a}$ Includes major damage only. 
The difference in the number of dwellings damaged by each disaster was sma11, except for the Lubbock, Texas tornado, which caused damage to only 2,033 dwe1lings compared to 50,457 by Hurricane Camille, 37,834 by the Agnes Floods, and 44,662 by the San Fernando Earthquake.

If the primary concern in disaster protection is to reduce the dollar property damages and the destruction of dwellings caused by natural disasters, then initial efforts might be directed toward mitigating the effects of hurricanes and floods. These two types of disasters have resulted in relatively higher property damages and destruction of dwellings than have earthquakes and tornadoes. If the concern is for reducing the loss of lives, then it may be more effective to invest in techniques for the mitigation of losses due to tornadoes, which have caused the greatest loss of lives. These conclusions, however, are based on an assessment of the potential benefits (reduction in losses) that might be realized by protecting against the adverse effects of natural disasters, with no examination of the costs of protection. Furthernore, there are various techniques of protection which need to be considered for any analysis of disaster protection。

\subsection{Recommendations for Further Research}

Additional research is needed to determine the real losses (i.e., in real dollar terms) that individuals and society experience from natural disasters。 Research is also necessary to determine 1) the future potential losses which natural disasters pose to various areas of the country and 2) the costs of alternative techniques for protecting against these losses. This additional research knowledge can be used as input for more comprehensive benefit-cost studies of alternative techniques of mitigating losses due to a variety of natural disasters.

Further research is also needed in the investigation of the economics and technology of different techniques of protection against disasters. Shoreline management practices that prevent building in flood-prone areas seem a viable alternative to the conventional engineering structures for reducing hurricane losses along the shoreline. 1 Dwellings can be better protected against flood waters through improved flood-proofing techniques or through location of buildings away from the reach of flood waters. Tornado losses can be reduced by providing better emergency shelters, more accurate prediction and warning systems, and structural modifications of existing and future buildings. Finally, earthquake losses can be reduced through improved earthquake-resistant construction, better land use management, and improved prediction techniques.

Research efforts can be applied to determining the technical effectiveness of disaster resistant provisions in building codes for reducing the losses from disasters. The economic consequences of instituting minimum building standards must be researched. Also, various economic incentives may exist to induce individual homeowners to purchase a given

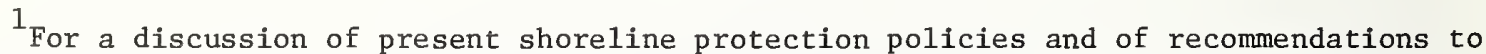
achieve more effective protection, see: U.S. Department of Commerce, National Bureau of Standards, Cost Sharing as an Incentive to Attain the Objectives of Shoreline Protection, by Harold E. Marsha11 (Washington, D.C.,: Government Printing Office, December 1973). 
level of protection against disasters. These incentives must be considered in lieu of or as complementary to building standards.

Although there are numerous techniques available for mitigating the losses from disasters, further research is needed to determine new and better techniques, reliability of existing techniques, improvements in existing techniques, and combinations of techniques that are most economically efficient for mitigating the losses due to natural disasters. 
This appendix is a mathematical note to show that minimizing total costs (costs of protection plus total losses) and maximizing net benefits (total benefits minus total costs) are two different techniques for achieving the same outcome--economic efficiency.

Cost minimization (see Figure 3.3) minimizes total costs (C), where total costs are the sum of the costs of protection (c) and total losses ( $\ell$ ). Both $c$ and $\ell$ depend on the level of protection $(P)$ against disasters. Symbolically,

$\begin{array}{ll} & c=c(\mathrm{P}) \\ \text { and } & \ell=\ell(\mathrm{P}), \\ \text { where } & c^{\prime}(\mathrm{P})>0 \\ \text { and } & l^{\prime}(\mathrm{P})<0 .\end{array}$

Formulating the minimization problem we obtain,

$$
\text { MIN } C=c(P)+\ell(P) \text {. }
$$

The first order condition requires that

$$
\begin{array}{ll} 
& c^{\prime}(P)+\ell^{\prime}(P)=0 \\
\text { or } \quad & c^{\prime}(P)=-\ell^{\prime}(P) .
\end{array}
$$

Economically speaking, we want to add increments of protection, $P$, until the increase in costs, $C^{\prime}(P)$ from the last increment just equals the decrease in losses, $l^{\prime}(P)$.

The efficiency criterion of the benefit-cost method (see Figure 3.1) is to maximize net benefits ( $B$ ); i.e., total benefits minus total costs. Total costs of protection, $c(P)$, are the same costs of protection that are considered under the cost minimization method. Total benefits are defined as the total losses that would occur ( $l$ ) in the absence of any disaster protection minus the total losses, $\ell(P)$, that occur as the result of protecting at the same level P. Since $c(P)$ and $\ell(P)$ are the same functions as those in the cost minimization method, they also behave the same. Thus $c^{p}(P)>0$ and $\ell^{\prime}(P)<0$. The maximization problem can now be formulated as follows:

$$
\operatorname{MAX} B=\left[\ell_{0}-\ell(P)\right]-c(P) \text {. }
$$

Deriving the first order conditions for maximization we obtain,

$$
\begin{aligned}
& -\ell^{\prime}(P)-c^{\prime}(P)=0 \\
& \text { or } \quad c^{\prime}(P)=-l^{\prime}(P)
\end{aligned}
$$

(since $\ell_{0}$ is a constant its derivative with respect to $P$ is zero). 
The conditions for economic efficiency, marginal costs equal to marginal losses, are the same as those under the cost minimization method. However, in the cost-benefit method we choose to call marginal losses marginal benefits since they are derived from total benefits. Furthermore, marginal benefits are merely the negative of marginal. losses; i.e.,

$$
\left.\frac{\mathrm{d}\left[\ell_{0}-\ell(\mathrm{p})\right.}{\mathrm{dP}}\right]=-\frac{\mathrm{d} \ell(\mathrm{p})}{\mathrm{dP}}
$$

or

$$
-\ell^{\prime}(p)=-\ell^{\prime}(p)
$$


American National Red Cross. Highlights of Disaster Relief Services, Fiscal Year 1959-60, $1961-62,1962-63,1963-64,1964-65$, and 1965-66.

- Annual Summary of Disaster Services Activities, 1966-67, 1967-68, 1968-69, $1969-70,1970-71,1971-72$, and 1972-73.

Anderson, Lee G. and Burnham, John M. "Applications of Economic Analysis to Hurricane Warnings to Residential and Retail Activities in the U.S. Gulf of Mexico Coastal Region." Monthly Weather Review, February 1973, pp. 126-131.

Dacy, Douglas C., and Kunreuther, Howard. The Economics of Natural Disasters. New York: The Free Press, 1969.

Executive Office of the President. Office of Emergency Preparedness. The Federal Response to Tropical Storm Agnes. A Report to the Senate Subcommittee on Public Works. Subcomittee on Disaster Relief. May 1973.

- Disaster Preparedness. Vo1. 1. Washington, D.C.: Government Printing Office, January 1972 .

- Disaster Preparedness. Vol。3. Washington, D.C.: Government Printing Office, January 1972 .

Friedman, Don G. "Prospective View of Natural Disasters in the United States." Paper presented at the Systems Safety Society Symposium, July 18, 1973.

- "Analysis for Earthquake Insurance." Paper presented at the Earthquake Research Affiliates Conference, California Institute of Technology, Apri1 3, 1973.

Kunreuther, Howard. "The Case for Comprehensive Disaster Insurance." Journal of Law and Economics, XI (April, 1968), pp. 133-163.

- Recovery from Natural Disasters, Insurance or Federal Aid?. Washington, D.C.: American Enterprise Institute for Public Policy Research, December 1973.

Russe11, Clifford S., "Losses from Natural Hazards." Land Economics, Vol. 46 (Nov. 1970), pp. 383-393.

U.S. Congress. Senate. Committee on Public Works. To Investigate the Adequacy and Effectiveness of Federal Disaster Relief Legislation, Part 2. Hearings before the 93rd Cong., lst. sess., March 30 and $31,1973$.

U.S. Congress. Senate. Commitee on Public Works. To Investigate the Adequacy and Effectiveness of Federal Disaster Relief Legislation, Part 3 . Hearings before the 93rd Cong., 1st. sess., May 11 and 12, 1973.

U.S. Department of Commerce. Environmental Science Services Administration. Coast and Geodetic Survey. A Preliminary Study of Engineering Seismology Benefits, by Joseph D. Crumlish and George F. Wirth, Washington, D.C.: Government Printing office, August 1967. 
U.S. Department of Commerce. National Bureau of Standards. Technical Analysis Division。 Cost Sharing as an Incentive to Attain the Objectives of Shoreline Protection, by Harold E。 Marsha11, Washington, D.C. NBSIR 73-294, December 1973.

U.S. Department of Commerce. National Oceanic and Atmospheric Administration. Environmental Data Service. Climatological Data, National Summary 1972, Vo1。23.

- Genera1 Summary of Tornadoes, $1965,1966,1967,1968,1969,1970,1971,1972$ 。 Asheville, NoC。

- Storm Data and Unusual Weather Phenomena. Asheville, NoCo, March 1973。

U.S. Department of Commerce. National Oceanic and Atmospheric Administration. Environmental Research Laboratories. A Study of Earthquake Losses in the San Francisco Bay Area: Data and Analysis. A Report Prepared for the Office of Emergency Preparedness, Part B, 1972 .

U.S. Department of Commerce. National Oceanic and Atmospheric Administration。 Nationa1 Weather Service. Tornado Preparedness Planning. Washington, D。C.: Government Printing Office, 0ct. 1970.

U.S. Department of Commerce. National Oceanic and Atmospheric Administration, Office of Hydrology。 A P1an for Improving the National River and Flood Forecast and Warning Service. Silver Spring, Md. 1969.

U.S. Department of Housing and Urban Development。 Federal Insurance Administration. Report on Earthquake Insurance to the Congress of the United States. Pursuant to Section Five of the Southeast Hurricane Disaster Act of 1965. Washington, D。C., 1971 . 


\begin{tabular}{|c|c|c|c|}
\hline $\begin{array}{l}\text { U.J. DEPT. OF COMM. } \\
\text { BIBLIOCRAPHIC DATA } \\
\text { SHEFT }\end{array}$ & $\begin{array}{l}\text { 1. PIIBI.ICATION OR REPORT NO. } \\
\text { NBSIR 74-473 }\end{array}$ & $\begin{array}{l}\text { 2. Gov't Aecession } \\
\text { No. }\end{array}$ & 3. Recipient's Accession Nis. \\
\hline \multirow[t]{2}{*}{$\begin{array}{l}\text { 4. TITLE AND SUBTITLE } \\
\text { Natural Disasters: }\end{array}$} & \multirow{2}{*}{\multicolumn{2}{|c|}{ Some Empirical and Economic Considerations }} & $\begin{array}{l}\text { 5. Publication Date } \\
\text { Febmuary } 1974\end{array}$ \\
\hline & & & 6. Performing Organization Codc \\
\hline \multicolumn{3}{|c|}{$\begin{array}{l}\text { 7. AUTHOR(S) } \\
\text { G. Thomas Sav }\end{array}$} & $\begin{array}{l}\text { 8. Performing Organ. Report No. } \\
\text { NBSIR } 74-473\end{array}$ \\
\hline \multicolumn{3}{|c|}{$\begin{array}{l}\text { 9. PEREORMING ORGANIZATION NAME AND ADDRESS } \\
\text { NATIONAL BUREAU OF STANDARDS } \\
\text { DEPARTMENT OF COMMERCE } \\
\text { WASHINGTON, D.C. } 20234\end{array}$} & 11. Contract/Grant No. \\
\hline \multirow{2}{*}{\multicolumn{3}{|c|}{$\begin{array}{l}\text { 12. Sponsoring Organization Name and Complete Address (Street, City, State, ZIP) } \\
\text { Office of Federal Building Technology } \quad \text { Washington, D.C. } \\
\text { Center for Building Technology } \\
\text { Building 226, Room A-266 } \\
\text { National Bureau of Standards }\end{array}$}} & $\begin{array}{l}\text { 13. Type of Report \& Period } \\
\text { Covered } \\
\text { Final }\end{array}$ \\
\hline & & & 14. Sponsoring Agency Code \\
\hline
\end{tabular}

15. SUPPLEMENTARY NOTES

16. ABSTRACT (A 200-word or less factual summary of most significant in formation. If document includes a significant bibliography or literature survey, mention it here.)

This study examines the extent of some of the losses resulting from natural disasters. An estimate of these losses is necessary in order to determine the potential benefits that might be realized from mitigating the negative economic impacts from natural disasters. Absolute and relative losses resulting from hurricanes, floods, earthquakes, and tornadoes are examined. This data will help individuals, communities, and the Federal govermment make better decisions as to how and what extent protection against disasters should be provided. The application of benefit-cost analysis for choosing the optimal level of protection against disasters is also discussed. Recommendations are made for further research in determining the economic feasibility of various techniques designed to mitigate the losses from disasters.

17. KEY WORDS (six to twelve entries; alphabetical order; capitalize only the turst letter of the first key word unless a proper name; separaced by semicolons)

Benefit-cost analysis; disaster mitigation; earthquakes; economics; efficient; floods; hurricanes; natural disasters; optimal; tornadoes; total cost minimization.

18. AVAILABILITY

X Unlimited

For Official Distribution. Do Not Release to NTIS

Orter From Sup. of Doc., U.S. Government Printing Office Washington, D.C. 20402, SD Cat. No. Ci3

Oider From Narional Technical Information Service (NTIS) Springfield, Virginia 22151

\begin{tabular}{|l|l|}
\hline $\begin{array}{l}\text { 19. SECURITY CLASS } \\
\text { (THIS REPURT) }\end{array}$ & 21. NO. OF PAGES \\
UNCL ASSIFIED & \\
\hline $\begin{array}{l}\text { 20. SECURITY CLASS } \\
\text { (THIS PAGE) } \\
\text { UNCLASSIFIED }\end{array}$ & 22. Price \\
\hline
\end{tabular}





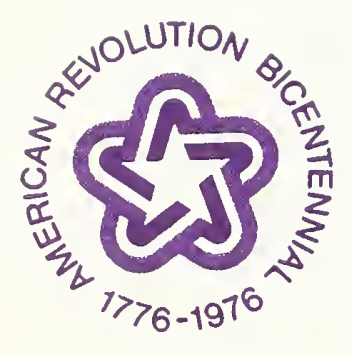

